\title{
Astrocytes Mediate Protective Actions of Estrogenic Compounds after Traumatic Brain Injury
}

\author{
Cynthia Martin-Jiménez ${ }^{\mathrm{a}}$ Diana Milena Gaitán-Vaca ${ }^{\mathrm{a}}$ Natalia Areiza ${ }^{\mathrm{a}}$ \\ Valentina Echeverria ${ }^{b, c}$ Ghulam Md Ashraf ${ }^{d}$ Janneth González ${ }^{a}$ \\ Amirhossein Sahebkar $^{\mathrm{e}-\mathrm{g}}$ Luis Miguel Garcia-Segurah, ${ }^{\mathrm{h}}$ George E. Barreto ${ }^{\mathrm{a}}$ \\ a Departamento de Nutrición y Bioquímica, Facultad de Ciencias Pontificia Universidad Javeriana, Bogotá, Colombia; \\ ${ }^{b}$ Universidad San Sebastián, Fac. Cs de la Salud, Concepción, Chile; ${ }^{\circ}$ Research and Development Service, Bay Pines \\ VA Healthcare System, Bay Pines, FL, USA; ${ }^{d}$ King Fahd Medical Research Center, King Abdulaziz University, Jeddah,

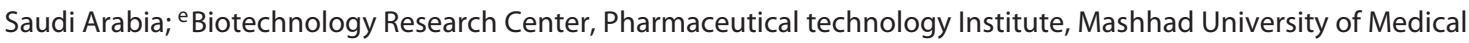 \\ Sciences, Mashhad, Iran; ${ }^{f}$ Neurogenic Inflammation Research Center, Mashhad University of Medical Sciences,

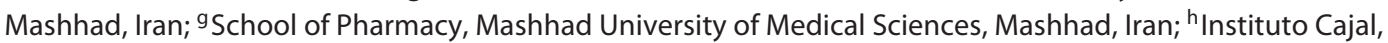 \\ CSIC, Madrid, Spain; 'Centro de Investigación Biomédica en Red Fragilidad y Envejecimiento Saludable (CIBERFES), \\ Instituto de Salud Carlos III, Madrid, Spain
}

\section{Keywords}

Astrocytes · Neuroprotection · Estrogenic compounds ·

Traumatic brain injury

\begin{abstract}
Traumatic brain injury (TBI) is a serious public health problem. It may result in severe neurological disabilities and in a variety of cellular metabolic alterations for which available therapeutic strategies are limited. In the last decade, the use of estrogenic compounds, which activate protective mechanisms in astrocytes, has been explored as a potential experimental therapeutic approach. Previous works have suggested estradiol (E2) as a neuroprotective hormone that acts in the brain by binding to estrogen receptors (ERs). Several steroidal and nonsteroidal estrogenic compounds can imitate the effects of estradiol on ERs. These include hormonal estrogens, phytoestrogens and synthetic estrogens, such as se-
\end{abstract}

\section{KARGER}

(C) 2018 S. Karger AG, Basel

E-Mail karger@karger.com

www.karger.com/nen lective ER modulators or tibolone. Current evidence of the role of astrocytes in mediating protective actions of estrogenic compounds after TBI is reviewed in this paper. We conclude that the use of estrogenic compounds to modulate astrocytic properties is a promising therapeutic approach for the treatment of TBI.

(c) 2018 S. Karger AG, Basel

\section{Introduction}

Traumatic brain injury (TBI) is generated by a traumatic event, which causes a strong impact on the brain and results in acute or chronic impairments in the func-

George E. Barreto, PhD

Departamento de Nutrición y Bioquímica

Facultad de Ciencias Pontificia Universidad Javeriana, Cra 7 40-62

Bogotá D.C. (Colombia)

E-Mail gsampaio@javeriana.edu.co, gesbarreto@gmail.com

Luis Miguel Garcia-Segura, $\mathrm{PhD}$

Instituto Cajal, CSIC

Madrid (Spain)

E-Maillmgs@ cajal.csic.es 
tion of neural cells [1]. TBI is a severe public health problem, particularly among male adolescents, young adults, and older people of both sexes [2]. Indeed, TBI is a familiar source of morbidity and mortality all over the world, whereby 69 million people are estimated to be affected by TBI each year [3]. Besides, it is the main cause of mortality and impairment among young people in the low- and middle-income countries [4]. Currently, brain injury has a higher frequency than other highly spread diseases such as cancer, acquired immune deficiency syndrome, Parkinson's disease and multiple sclerosis [1]. TBI has heterogeneous aetiology, type, severity and outcomes. There are 2 main types of TBI: penetrating and non-penetrating. Penetrating TBI is an open lesion in the head causing intracranial hemorrhage. Non-penetrating TBI causes brain damage because of indirect impact without penetrance of any objects into the brain [5]. As a result of TBI, one or more brain regions are damaged and become swollen $[3,6]$.

Despite the availability of standardized treatment guidelines and improvements in understanding the mechanisms of cellular damage, therapeutic strategies for patients with TBI remain unsatisfactory because of their reduced efficacy in preventing the metabolic changes and brain dysfunctions caused by the injury. Brain responses to damage and disease involve several cell types that interact with each other in an attempt to preserve cell viability and homeostatic physiological function [7]. In the last few years, protective strategies have been focused on modulating the responses of different brain cells to injury. In this regard, astrocytes may represent relevant candidates, since they play critical roles in the central nervous system (CNS) both under healthy and pathological conditions. In the healthy CNS, astrocytes accomplish a significant number of homeostatic functions, including the control of neuronal metabolism, production of antioxidants and regulation of synaptic transmission and plasticity. In addition, astrocytes respond to brain injury with a series of morphological, metabolic and cellular changes involved in the protection of the damaged neural tissue [8]. Studies with intravital time-lapse imaging have shown that ATP and other metabolites released by astrocytes play a pivotal role in stimulating beneficial cellular responses after brain injury [9]. Therefore, the identification of molecules/compounds that activate protective mechanisms in astrocytes may lead to the development of potential therapeutic strategies for TBI [10-12].

Estrogenic compounds include a wide variety of natural and synthetic steroid and non-steroid molecules that bind to ERs, thereby mimicking the activity of estradiol in different tissues. Estrogenic compounds can affect astrocytes, either directly or indirectly, and exert numerous actions in the CNS under physiological and pathological conditions [13]. For instance, it has been shown that estrogenic compounds regulate oedema, extracellular glutamate levels, reactive astrogliosis and inflammatory response after brain trauma $[14,15]$. Therefore, they may be useful molecules for the management of TBI [11]. In the next sections, we review the participation of astrocytes in the response of neural tissue to injury and their role in mediating neuroprotective actions of estrogenic compounds to improve neuronal survival and functional outcomes after TBI.

\section{Cellular and Molecular Alterations after TBI}

Depending on the outcome of damage to brain parenchyma, the tissue injury produced by TBI is classified into 2 substantially different stages associated with different mechanisms of neural damage: primary and secondary [16]. The primary injury occurs as a consequence of the initial physical insult [17]. This stage often requires surgical attention and happens at the moment of trauma, when tissues and blood vessels are extended, compacted, and damaged [6]. The secondary stage appears hours to days later as a consequence of the activation of signalling pathways that provoke oedema, inflammation and brain cell death [16]. The secondary injury is characterized by high levels of lactate [18], oxygen-free radicals [1], interleukins [19] and intracellular free $\mathrm{Ca}^{2+}$ in response to the primary injury [20]. In addition, impairment of the blood-brain barrier (BBB), excessive release of the neurotransmitter glutamate and dysfunction of mitochondria in the brain [21] contribute to the secondary injury. Other alterations that can be detected in secondary brain injury are decreased brain blood flow, ischemia, increased reactive oxygen species (ROS) and brain cell death [22].

In comparison with primary injuries, secondary ones are progressive, a fact that can be vital for patient recovery [23]. TBI may be associated with different injuries in other body regions (limb fractures, thoracic, or abdominal injuries) [24], which increase the risk of secondary brain injury due to hypotension, hypoxia, pyrexia and coagulopathy. In addition to brain cell death, TBI is associated with neuroinflammation, axonal damage and vascular abnormalities [25]. TBI includes anomalous ranges of oxygenation, upregulation of inflammatory pathways and irregular endocrine secretion [26]. Interestingly, there is evidence suggesting that neuroendocrine dysfunction 
might contribute negatively to the severity and the TBI outcome [27]. Recent studies using controlled cortical impacts in mice have demonstrated that the alterations in growth hormone levels after brain injury are associated with a disruption in barrier organization of tanycytes [28, 29]. It has been suggested that these cells play a crucial role in the maintenance of $\mathrm{BBB}$, the control of the pituitary function and the secretion of active compounds. All these functions, which are critical to the protection of the homeostasis of the brain, have highlighted the important role of tanycytes during TBI [30].

The early secondary stages of cerebral injury after TBI are characterized by the accumulation of lactic acid due to an increase in anaerobic glycolysis, excess membrane permeability and oedema $[22,31]$. The latest pathological stages are characterized by excessive production of excitatory neurotransmitters (glutamate, aspartate), and activation of $\alpha$-amino-3-hydroxy-5-methyl-4-isoxazolpropionate, N-Methyl-D-aspartic acid and voltage-dependent calcium and sodium channels, which consequently generate terminal membrane depolarization and mitochondrial dysfunction $[32,33]$. The imbalance of calcium and sodium intake could trigger autophagy mechanisms [34], activation of caspases, translocases and endonucleases, and inhibition of DNA repair, which may induce structural modifications of biological membranes and DNA damage $[35,36]$. Consequently, all these events lead to membrane decoupling and finally cell death by necrosis and apoptosis [37]. Furthermore, the excessive production of excitatory neurotransmitters causes excitotoxicity. In this regard, excitotoxicity could lead to excessive stimulation of glutamate receptors, occasioning damage and death of brain cells. Neurons are especially vulnerable to excitotoxicity [38]. Furthermore, astrocytes are less vulnerable and reuptake glutamate from synapses, thanks to their fast conversion from glutamate into glutamine by the glutamine synthetase, thus preventing the excessive and toxic extracellular glutamate accumulation [39].

Excitotoxicity induces harmful effects on the mitochondrial electron transport chain that generates the oxidation of cellular structures and molecules by the newly generated oxidative species [40]. Indeed, another cell death mechanism elicited by TBI is oxidative stress caused by increased levels of ROS and reactive nitrogen species (superoxide, hydrogen peroxide and nitric oxide) [41]. This mechanism is fundamental due to the fact that the brain is highly susceptible to free radical damage because of its oxidative metabolism and its high levels of polyunsaturated lipids [42]. Some studies have demonstrated that superoxide radicals and nitric oxide impair cerebral

Table 1. Astrocyte functions under physiological conditions

Function

Control of cerebral blood flow by the regulation of

vascular tone

Uptake of glutamate and GABA

Adjustment of synaptic transmission

Antioxidant functions related with key proteins involved in neutralizing damaging free radicals in the form of reactive oxygen species

Organization of the structural architecture of the brain

Preservation of neural tissue and restriction of inflammation after moderate focal brain injury

Regulation of brain homeostasis

[235]

[229]

[230]

[231]

[232]

[233]

[234]
References

vascular function after TBI due to their strong oxidative effects $[43,44]$.

Increased levels of ROS can be triggered not only by an increase in their generation, but also due to a decreased capacity of the enzymatic antioxidant system (superoxide dismutase, glutathione peroxidase and catalase). In this regard, it is relevant to note that astrocytes maintain high expression of intracellular antioxidant enzymes. This antioxidant activity of astrocytes helps to protect the neuron against the oxidative stress preventing the damage of DNA, RNA, and proteins $[45,46]$. In this regard, previous works indicated that astrocytes are pivotal mediators in TBI due to their ability to provide neurons (and other cells) metabolic support [47-49].

\section{Role of Astrocytes after TBI}

\section{Function of Astrocytes under Physiological and} Pathological Conditions

Astrocytes are the most abundant group of glial cell, representing approximately around $20-40 \%$ of the total brain cell population $[48,50,51]$. Their function depends on their shape, position, subtype, developmental stage and metabolic state [48]. Astrocytes are recognized for being multifunctional housekeeping cells involved in a permanent cross-talk with neurons and other neighbouring glial cells [52]. They regulate the concentration of potassium, sodium and glutamate at the synaptic cleft [4749], provide lactate and glutamine to neurons and participate in neuron signalling modulation [53-57]. 
Table 2. Molecules with the ability to activate astrocytes

\begin{tabular}{llc}
\hline Processes & Activating molecules & References \\
\hline Growth factor and interleukins & TGF $\beta$-1, TNFa, INF $\gamma$, IL-1 $\beta$, Il6, LIF, CNTF, Il1, Il10, IL-6, and EGF & {$[236-239]$} \\
Inflammatory modulators & LPS, TLRs, DAMPs, PAMPs & {$[74,94,240,241]$} \\
Cytotoxicity & Glutamate, ammonia & {$[242,243]$} \\
Oxidative stress & ROS, H2O2, NO, O2- and OH & {$[84,113,244]$} \\
Neurodegenerative diseases & Amyloid-beta, alpha-synuclein and presenilin & {$[84,245,246]$} \\
Brain damage & Hypoxia, glucose deprivation and TBI & {$[113]$} \\
\hline
\end{tabular}

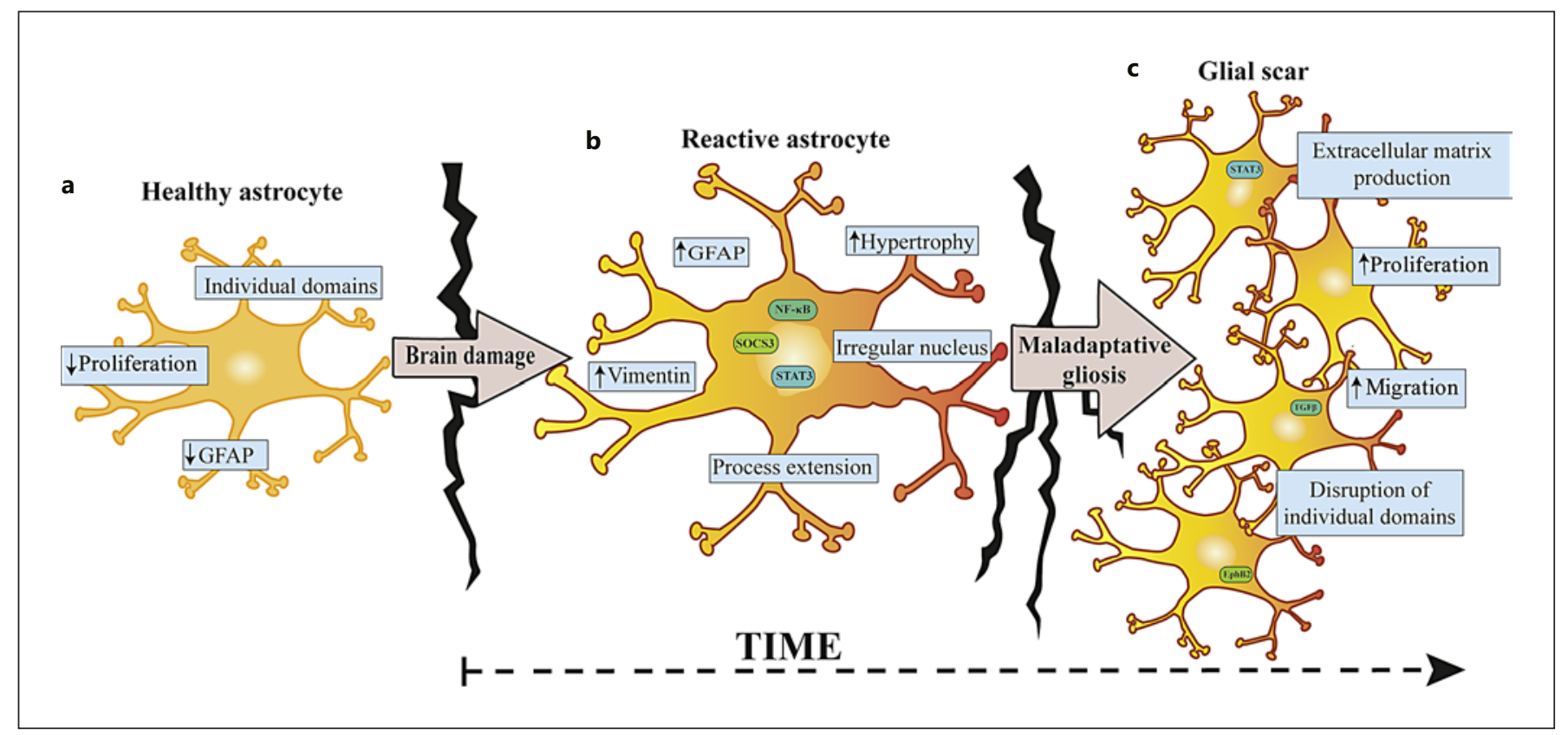

Fig. 1. Schematic representations of different phenotypic changes in reactive astrogliosis. a Healthy astrocytes have many physiological functions aimed to maintain CNS homeostasis. b Under pathological conditions, astrocytes undergo a variety of phenotypic and functional changes, known as reactive astrogliosis. Reactive astrocytes show a variety of changes in the activation of specific signalling cascades, such as STAT3, SOCS3 or NF- $\kappa$ B, cellular morphol-

The different physiological functions of astrocytes are listed in Table 1. For instance, in a healthy and uninjured CNS, astrocytes play an essential role in the modulation of potassium, sodium, calcium and glutamate levels in the extracellular space, thus modulating synaptic activity and preventing excitotoxic cell death [58-60]. Astrocytes have cell processes that contact with blood vessels, neuronal perikarya, axons, and synapses. Thus, these cells uptake glucose from blood vessels and supply energy metabolites, such as lactate, to neurons [61]. Besides the production gliotransmitters and growth factors, astrocytes ogy and alterations in the expression of intermediate filament proteins such as nestin, glial fibrillary acidic protein (GFAP) and vimentin. c Astrogliosis progress over the time and this can become maladaptive, whereby scar formation takes place. Glial scar includes alterations in molecular expression and functional features. 
Table 3. Specific signaling cascades involved in the morphological and functional modifications of reactive astrocytes

\begin{tabular}{|c|c|c|}
\hline Astrocyte morphological and functional changes & Signaling pathways implicated & References \\
\hline Hypertrophy & STAT3, Endothelin-1 & {$[76,247]$} \\
\hline Proliferation & Endothelin-1; JAK/STAT3, JNK/c-Jun and Olig2 & {$[104,248]$} \\
\hline Scar formation & STAT3; EphB2, fibrinogen, TGF $\beta$, FGF2 & {$[76,250]$} \\
\hline Release of pro-inflammatory molecules & NF-кB; P2X7; MAP-kinase & {$[75,251,252]$} \\
\hline Release of anti-inflammatory molecules & STAT3; Nrf2; SOCS1 and SOCS3 & {$[76,253-255]$} \\
\hline Protection by antioxidant response & Nrf2 & {$[254,255]$} \\
\hline
\end{tabular}

cytes [65]. Likewise, the role of astrocytes may be supported by tanycytes and microglia. For instance, tanycytes are cells with morphological and molecular characteristics similar to those of astrocytes and are responsible for transporting substances from the cerebral spinal fluid and the blood portal $[30,66,67]$. Estrogen receptors (ERs) have been identified in tanycytes and microglial cells and it has been observed that they help in estrogenic communication, as estradiol stimulates the secretory activity of these cells by releasing prostaglandin E, which is related to synaptic alterations in the hippocampus, as well as in astrocytes $[67,68]$. As discussed later, the interaction of astrocytes with other brain cells plays a fundamental role in neuroprotection [68].

Under pathological conditions, astrocytes undergo a variety of phenotypic and functional changes, known as reactive astrogliosis. Generally, this pathological phenomenon is related to an enhanced proliferation and secretion of inflammatory mediators, adhesion molecules and growth factors [69-74]. Reactive astrogliosis is elicited by a variety of molecular signals (Table 2) associated with different forms of CNS injuries and diseases such as trauma, ischemia, infection, stroke, neurological disorders and neurodegenerative diseases [71]. Compared to non-reactive astrocytes, reactive astrocytes show various alterations in gene expression, activation of specific signalling cascades, such as signal transducer and activator of transcription 3, suppressor of cytokine signalling 3 or nuclear factor $\kappa \mathrm{B}(\mathrm{NF}-\mathrm{\kappa B})$ and exhibit morphological and functional changes (Fig. 1) [75-78]. These changes depend on the severity of the damage (Table 3) [51, 72, 7985]. Previous histopathological studies of the human brain have shown various grades of reactive astrogliosis [84]. Mild to moderate astrogliosis are caused by different insults including TBI, and viral and bacterial infections. When the brain tissue presents mild or moderate injury, astrocytes experiment hypertrophic astrogliosis and pro- cess hypertrophy [84]. These changes include modifications in the expression of the glial fibrillary acidic protein (GFAP), vimentin, nestin and other proteins [85], which alter the normal cellular structure, energy metabolism, intracellular signalling, and pump activities of astrocytes [84]. In severe cases of brain injury, astrocytes undergo progressive cellular hypertrophy, proliferation and scar formation [7].

Astrogliosis can be interpreted as a homeostatic response aimed to reduce and repair the initial damage, maintaining brain function $[51,74]$. However, depending on the different stages of the insult and its progress over time, astrocytes are capable of playing beneficial or detrimental actions $[84,86]$. A number of experimental studies have shown that astrogliosis has an essential role in the recovery after a TBI or ischemia, due to their ability to isolate the still health brain tissue [74, 87-89]. Reactive astrocytes have a beneficial role in the acute response after brain trauma because they may limit the extension of damage, and separate the harmful lesion from the rest of the CNS thus preventing its spreading. Studies using genetic ablation of GFAP and vimentin at the time of injury have shown a significant reduction in astrogliosis, a slower response to damage and a decrease in the integration of new neuronal synapses after TBI [82]. Interestingly, this acute ablation increases the number of leukocytes that cross the $\mathrm{BBB}$, leading to neuronal degeneration [87]. On the other hand, it seems like that reactive astrocytes respond to brain injury by expressing aromatase. This enzyme is involved in the synthesis of different estrogens in humans (E1, E2, E3). The increase in the local expression of estrogens may be involved in the neuroprotective and regenerative effect in the brain [90]. It is important to point out that astrogliosis progresses over the time and becomes harmful in chronic stages. In these stages, reactive astrocytes are known to inhibit axonal regeneration and the integration of neurons after brain injury [86, 91-93]. 
Reactive astrocytes also can release chemokines, growth factors, proteases and danger-associated molecular patterns, which could be beneficial or detrimental for the BBB integrity in various ways $[7,94,95]$. For example, different studies have shown that astrocytes secrete apolipoprotein $\mathrm{E}$ and the vasoactive endothelial growth factor in response to stimulation with inflammatory mediators [96], increasing BBB permeability and causing leukocyte infiltration $[7,94,97,98]$.

\section{Astrocytes and the Glial Scar}

Scar formation takes place in most lesions that cause severe tissue damage, such as penetrating trauma. In this process, astrocytes undergo severe morphological changes with the spread of long branched processes that overlap [84]. In the pathologic process, reactive astrocytes cooperate with the different brain cells and interact with the extracellular matrix to generate the glial scars $[76,84,99]$. These scars persist for long periods of time even when the causes of the brain damage have disappeared $[76,87,89$, 100]. The glial scar is formed in damaged zones that contain surviving neurons where these glial formations can interact with neuronal and non-neuronal cells in the area around the lesion [87, 101-103]. It has been proposed that in this process of scar formation are involved some molecular triggers that initiate the spread of reactive astrocytes in vivo such as ATP, the signal transducer and activator of transcription 3, fibroblast growth factor, epidermal growth factor, and endothelin 1, which can diminish or aggravate the brain damage [104-106]. However, the origin of newly scar-forming astrocytes is not well established. Different hypotheses have been postulated, such as that mature astrocytes have the capability of starting the cell cycle and multiply in the moment of scar formation $[87,104,107]$. There is also evidence that some of the proliferating astrocytes after brain damage derive from polydendrocytes, cells that express the neu$\mathrm{ral} /$ glial antigen 2 proteoglycan [108], in the brain parenchyma and progenitors of ependymocytes [109, 110]. Besides, it is also postulated that other source of scar-forming astrocytes could be multipotent progenitors in ependymal and subependymal tissues expressing GFAP [84]. These progenitors might produce cells with the capacity of migrating to locations of injury [111].

Recent evidence indicates that the glial scar seems to have a beneficial role by forming a compact barrier that isolates the healthy tissue of damaged tissue and does not allow the red and white blood cells to have contact with the healthy tissue [80]. Glial scar plays also a significant role in the regulation and the control of the propagation of CNS inflammation [84]. By contrast, there are studies showing the negative effects of reactive gliosis and glial scar. For instance, experiments in animal models suggest that the suppression of glial scar formation might improve the outcome after diverse types of CNS injuries by reducing excitotoxic neurodegeneration $[87,112,113]$, inducing inflammation $[76,87-89,114,115]$ and improving axonal regeneration [116]. The glial scar can also exert other negative effects. For example, there is also evidence showing that glial scar impedes axonal regeneration and reduces axonal re-growth. As described above, the negative effects of astrogliosis and glial scar have been related to late chronic phases, specifically, when reactive astrocytes are not able to appropriately respond to damage during post-acute and early chronic stages after TBI [116]. Consequently, nerve cells are exposed to harmful molecules for a long time, which also have some deleterious long-term effects in the injured brain. Altogether, accumulating evidence has suggested that astrocytes seem to play a critical determinant role in acute and chronic stages after TBI. Their beneficial and detrimental responses can directly affect neuronal survival [117]. For this reason, astrocytes (and astrogliosis) have been postulated as an important therapeutic target for the action of different neuroprotective substances, such as estrogenic compounds. These compounds have been implicated in the activation of different protective cellular pathways in the CNS.

\section{The CNS as a Target for Neuroprotective Estrogenic Compounds}

Numerous studies have shown that synthetic or natural estrogens, such as estradiol, phytoestrogens, selective ER modulators (SERMs) and tibolone, exert neuroprotective actions in vitro and in vivo (Fig. 2) [10, 118-137]. Thus, there is evidence showing that estrogens reduce neuronal death in rodent models of TBI [138] and prevent damage in several pathological conditions affecting the CNS such as cerebral ischemia and Alzheimer's disease [139]. This opens the possibility of the development of neuroprotective estrogenic drugs to support cognitive function and to decrease damage after brain injury [10, $128,140,141]$.

\section{Endogenous Estrogens}

Endogenous estrogens are steroid hormones recognized for their participation in the development and maintenance of the female sexual characteristics. There are mainly 3 types of hormonal estrogens: E2, which oc- 
Fig. 2. Estrogenic actions on astrocytes. Estrogenic compounds (EC) exert different actions on astrocytes through ER $\alpha, E R \beta$ and GRP30. (1) Estrogenic compounds may have beneficial effects after brain injury through the regulation of reactive gliosis; (2) increase in the production and release of different molecules, such as neuroestrogens and neurotrophic factors (TrkA, BDNF and ChAT), with the subsequent decrease of neuronal death after brain injury; (3) regulate glutamate transporter GLT-1 and GLAST expression in astrocytes, thus maintaining optimal glutamate levels; (4) reduce the formation of ROS and decrease the loss of antioxidant glutathione, with the subsequent recovery of the mitochondrial membrane potential, ATP production and decreasing cell death; (5) preserve mitochondrial function in astrocytes through $\mathrm{ER} \alpha / \beta$. Likely, ERs may inhibit (a) apoptotic signalling and (b) regulate the expression of mitochondrial proteins, proton channels and subunits of key enzymes of the respiratory chain, as well as by eliminating radical oxygen species (ROS); and (6) decrease the inflammatory response in astrocytes reducing neuroinflammation through a decrease in the expression of IL- $1 \beta$, IL- 6 , tumor necrosis factor (TNF- $\alpha$ ) and TNF- $\beta$.

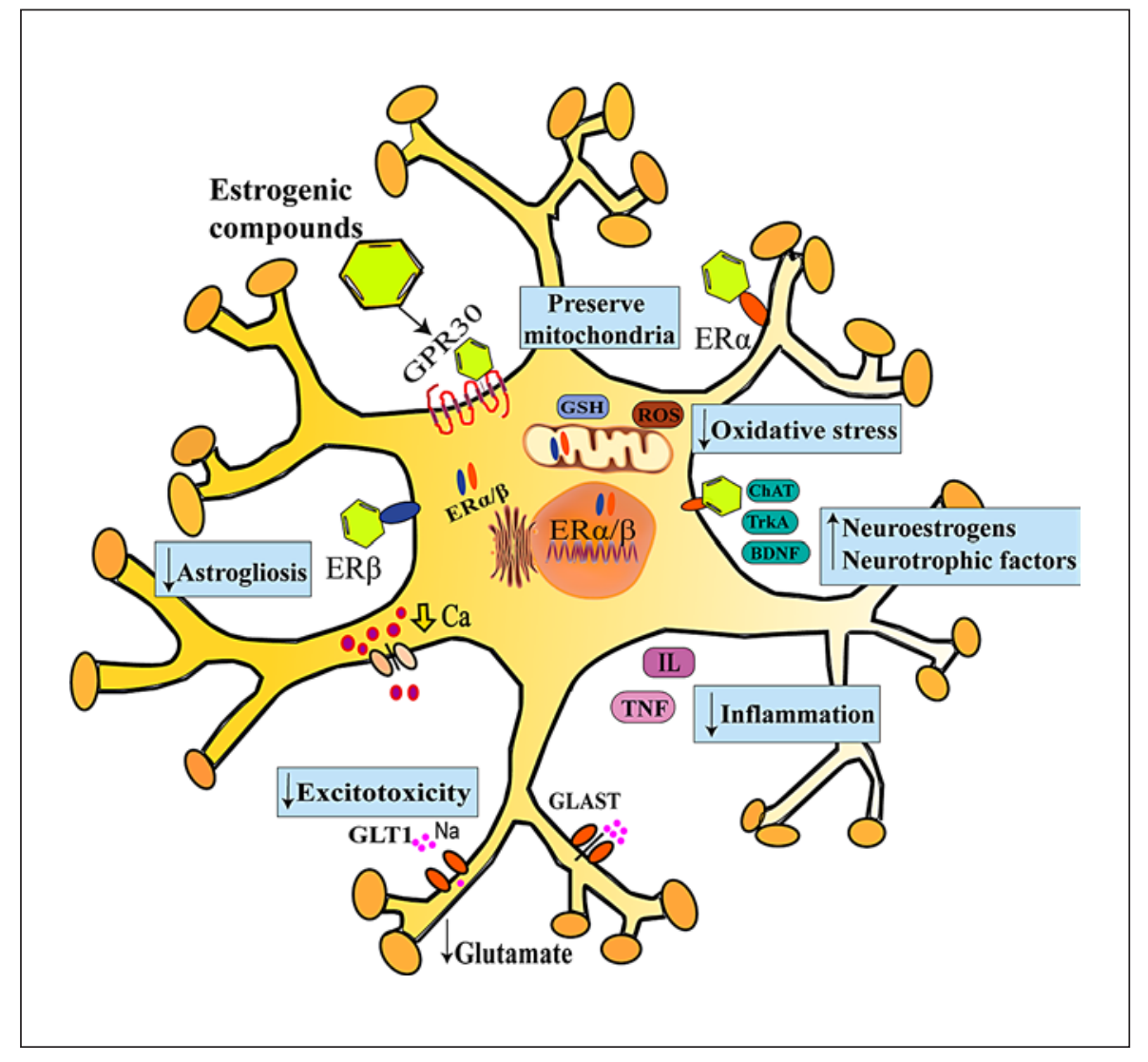

curs in higher concentrations in women of fertile age, estrone (E1) that predominates in menopausal women and estriol (E3), which is the primary estrogen during pregnancy [142]. The most potent endogenous estrogen is estradiol, which is produced by the growing follicle and its levels vary across the menstrual cycle, peaking just before ovulation [143]. The placenta, adrenal glands, testicles and adipose tissue are also estrogen-secreting organs [143]. Estrogens are also reported in men in the form of estradiol, which is produced by perifereral aromatization of testosterone in adipocytes and tissues that require the action of estrogens such as bones and the brain [144]. Hormonal estrogens act through their binding to the classical alpha and beta ERs (ER $\alpha, E R \beta)$. These classical ERs are ligand-activated transcription factors that once bound to estrogens form dimers that interact with ER response elements (EREs) located in the promoter regions of some genes [145]. In addition, classical ERs can modulate other genes without interacting with ERE regions by the regulation of different signalling pathways [142]. Furthermore, hormonal estrogens may also activate different signalling pathways acting on G-protein coupled ER [146].
ERs are expressed in different tissues, being predominant the ERa in women with greater expression not only in the uterus, but also in liver, adipose tissues, skeletal muscle, pituitary and hypothalamus, while ER $\beta$ is present in ovaries, prostate and in the brain [147], suggesting an important role of ERs in different tissues [148].

For many years, it has been known that hormonal estrogens act in different organs such as bones, heart and brain, exerting effects beyond the control of reproductive function [149]. ERs have been identified in diverse brain regions such as the neocortex, amygdala and hippocampus, suggesting an effect of hormonal estrogens on cognition, mood and other general brain functions. Furthermore, the expression of ERs has been identified in microglia, neurons and astrocytes [122, 149-151].

\section{Phytoestrogens}

Phytoestrogens are estrogenic molecules produced by plants that are involved in vegetal development, healing and reproduction. Phytoestrogens are mainly found in the Leguminosae family and occur in different parts of the plant such as seeds and fruits [152]. Phytoestrogens are 
classified into 4 groups: isoflavones, lignans, coumestans and stilbenes, and these can be obtained through diet [153]. Isoflavones have been extensively studied, among which daidzein and genistein are the most recognized compounds and are found mainly in soy and red clover. Lignans are found in linseed, in grains such as wheat, rye and oat, and in various types of berries. Coumestans are present in small amounts in red clover and alfalfa, and lower concentrations are found in lima bean and sunflower seeds [154]. Of the stilbenes, the most recognized is resveratrol that is present in the skin of grapes, peanuts and cranberries $[153,154]$.

Once in the intestine, intestinal bacteria hydrolyze phytoestrogen to the aglycone form by removing the sugar residue(s). The aglycones are absorbed by the enterocytes, conjugated in the liver and released into the blood. In some cases, metabolites of phytoestrogens are absorbed easier than the parent compound; for example, phytoestrogen enterolactone is produced from lignanosecoisolariciresinol by the action of colon bacteria, which is then absorbed by the enterocytes and released into the bloodstream [152].

Phytoestrogens have attracted the attention because of their structural similarity with estradiol. This particular characteristic has positioned the phytoestrogens as natural alternatives for the treatment of menopausal symptoms. Phytoestrogens are also considered potential complementary treatments for osteoporosis, cardiovascular diseases and CNS diseases [154]. The neuroprotective activity of phytoestrogens may be mediated by the affinity of these compounds to ERs, in particular to ER $\beta$ [154].

Few studies have focused on determining the effect of phytoestrogens on astrocytes. Among phytoestrogens, the most studied have been genistein and daidzein, which increase iron transport, increased as a result of oxidative stress [155], protect DNA and mitochondrial function [156], and exert anti-inflammatory effect by inducing the expression of antioxidant enzymes such as inducible nitric oxide synthase (iNOS) and cyclooxygenase (COXs) [157] and peroxisome proliferator-activated receptor (PPARs) [158] in different astrocytic cell lines.

Studies performed by Soltani et al. [159] have revealed a protective effect of the isoflavone genistein against TBI by inhibiting the development of cerebral oedema, suppressing the increase of intracranial pressure and diminishing motor damage. Genistein has also shown to reduce excitotoxic neuronal death in the rat hippocampus, induced by the systemic administration of kainic acid [122]. Similarly, resveratrol has been shown to protect brain functions against hypoxia-ischemia induced by neonatal rat brain injury that causes impairment of sensorimotor abilities, neurological reflexes, learning and memory [160]. Despite the above-mentioned evidence, more research is needed to better understand the mechanisms underlying the action of phytoestrogens in the brain, in order to implement the use of these compounds for controlling the symptoms of estrogen deficiency and protecting brain function in postmenopausal women.

\section{Synthetic Estrogenic Compounds}

Selective ER Modulators

SERMs are synthetic molecules, which depending on the tissue act as ER agonists or antagonists. The first synthesized SERM was tamoxifen. This molecule was first considered an antagonist of ERs due to its antagonistic effect in ER-positive breast cancers. Later, it was discovered that tamoxifen acts as an ER agonist in other tissues and the concept of SERM was developed. Nevertheless, it is possible to find in the market first-generation SERMs, such as tamoxifen and toremifene that are used in the treatment of breast cancer. The second-generation drug, raloxifene, is an antagonist of ERs in ER-positive uterine and mammary cancer cells, while it is used as an ER agonist in bone for the prevention of osteoporosis. Finally, there are also third-generation SERMs including bazedoxifene, lasofoxifene and ospemifene that are being used primarily in combination therapies with other estrogenic compounds for the treatment of postmenopausal symptoms $[161,162]$.

The binding of SERMs to the ligand-binding domain of ERs causes specific conformational changes in the receptors that determine which tissue-specific coregulators of transcription could be recruited to the transcriptional complex [162]. Thus, the transcriptional response to SERMs varies according to the specific SERM, the specific ER and the presence of tissue-specific transcriptional cofactors, resulting in different transcriptional outcomes in different tissues and organs $[162,163]$.

SERMs have been extensively studied for their agonist activities and selective effects in the brain, acting on neurons, glial cells, astrocytes and microglia. Some SERMs have neuroprotective effects by acting as antioxidants, decreasing neuroinflammation and gliosis, stimulating neurotrophic factors, such as the brain-derived neurotrophic factor (BDNF), regulating mitochondrial functions and promoting neuronal survival $[8,128,164]$. In addition, SERMs, such as raloxifene and tamoxifen, have been shown to be neuroprotective in animal models of Parkinson's disease by stimulating the phosphatidyl- 
inositol 3-kinase (PI3K)/Akt/GSK3 $\beta$ signalling pathway $[161,165]$. Furthermore, tamoxifen promotes functional recovery in animal models of spinal cord injury [270].

\section{Tibolone}

Tibolone is a synthetic steroid that belongs to a group of molecules so-called selective tissue estrogenic activity regulators (STEARs), which have estrogenic, progestogenic and androgenic properties. Selective tissue estrogenic activity regulators, in particular tibolone, are also used in hormone therapy aiming at the reduction of postmenopausal symptoms [166].

When tibolone is metabolized, 3 steroid compounds are produced: delta-4 isomer, a 3-alpha-hydroxy metabolite and a 3-beta-hydroxyl metabolite. The 3-OH metabolites bind to ER, and the delta-4 isomer binds to both androgen and progesterone receptors [167]. A study performed on ovariectomized cynomolgus monkeys treated orally with $0.5 \mathrm{mg} / \mathrm{kg} /$ day tibolone for 36 days showed an increase of estrogenic metabolites in the hypothalamus that was correlated with a reduction in the number and severity of hot flushes and perspirations. The combined effect of tibolone on androgen receptor and ERs is responsible for improving the libido, mood and general well-being [168]. Also, it has been reported in an in vivo study that an increase in antioxidant activity may underlie the neuroprotective effects of tibolone. Specifically, the treatment of Wistar adult rats with $1 \mathrm{mg} / \mathrm{kg}$ of tibolone for 30 days prevented the oxidation of membrane lipids and proteins in the hippocampus. Furthermore, the administration of the same dose of tibolone for 60 days decreased neuronal cell death caused by ozone in the CA3 region of the hippocampus [264]. Given the above-mentioned findings, tibolone has also been proposed as a therapeutic agent for brain damage including TBI because of the ability of its metabolites to act on different sex steroid receptors, such as ER $\alpha$ and ER $\beta$, and improving physiological functions. In this regard, astrocytes are postulated as mediators of the action of tibolone in the CNS [118]. Indeed, a recent study has shown that tibolone reduces reactive astrogliosis in a model of TBI in ovariectomized female mice [169].

\section{Neuroprotective Actions of Estrogenic Compounds after TBI}

Estrogenic compounds reduce the extent of the injury, the sensorimotor and working memory deficits, and reactive astrogliosis after TBI [123, 124, 133, 170-175]. For instance, estradiol has been shown to reduce intracranial pressure, oedema formation and BBB permeability in female rats after TBI [176]. The SERM raloxifene increases neurotransmitter receptor binding in brain regions associated with cognition and memory, and enhances the transcription and protein levels of neurotrophic factors such as tropomyosin receptor kinase A (TrkA), BDNF and ChAT in experimental models of TBI in rats [177]. Another SERM, tamoxifen, has been shown to reduce tissue damage and promote functional recovery after traumatic injury of the spinal cord [202]. The phytoestrogen resveratrol reduced neuronal loss in all ipsi- and contralateral hippocampal regions while improving exploratory activity and memory abilities in albino Wistar rats submitted to TBI [178]. Another phytoestrogen, genistein, reduced cerebral oedema, BBB permeability and intracranial pressure while improving motor conditions [159]. Similar protective actions have been reported for puerarin, an isoflavone glycoside isolated from the Chinese herb Radix Puerariae [179, 180].

\section{Mechanisms Involved in the Neuroprotective Actions} of Estrogenic Compounds after TBI That Are

Mediated by Astrocytes

In vitro studies indicate that astroglial cells are directly or indirectly regulated by estrogenic compounds. Direct actions have been demonstrated in primary rodent astrocytes cultures where, for instance, estradiol regulates the activation of ERK1/2, PI3K and NF- $\kappa B$ signalling $[181,182]$. That astrocytes may be direct targets of estrogenic compounds is also suggested by the finding that they express ERs both in vitro [181, 183-188] and in vivo, in particular after brain injury $[14,128,151,164$, 189-195]. In addition, there is evidence that estradiol anti-inflammatory and protective effects in experimental autoimmune encephalomyelitis is dependent on the expression of ER $\alpha$ in astrocytes [196-198], indicating that these cells may mediate neuroprotective actions of estrogenic compounds. In the next subsections, we review the mechanisms regulated by estrogenic compounds in astrocytes that may mediate neuroprotection after TBI (Table 4).

\section{Regulation of Astrogliosis}

Estrogenic compounds may have beneficial effects after brain injury through the regulation of reactive gliosis and the production of different molecules by reactive astrocytes [123]. In vivo studies have shown that several estrogenic compounds, such as estradiol, phytoestrogens (genistein), some SERMs and tibolone, decrease reactive 
Table 4. Estrogenic compounds and mechanisms of astrocytic-induced neuroprotection in TBI

\begin{tabular}{|c|c|c|c|c|c|}
\hline $\mathrm{EC}$ & Compound & Model & Mechanisms & Protective effect & References \\
\hline \multirow[t]{3}{*}{$\begin{array}{l}\text { Natural } \\
\text { Estrogens }\end{array}$} & $\begin{array}{l}\text { Estrogen } \\
(33.3 \mathrm{mg} / \mathrm{kg} \\
\text { and } 1 \mathrm{mg} / \mathrm{kg})\end{array}$ & Albino N Mary rats & Inflamation by IL- $1 \beta$, TGF- $\beta$ & $\begin{array}{l}\text { Preventing BBB disruption, decreasing the } \\
\text { brain level of IL- } 1 \text { b and increasing the level } \\
\text { of TGF- } \beta \\
\text { Co-administration has an inhibitory effect on } \\
\text { brain edema }\end{array}$ & {$[226,259]$} \\
\hline & $\begin{array}{l}17 \beta \text {-estradiol } \\
(1-5 \mathrm{mg} / \mathrm{kg})\end{array}$ & $\begin{array}{l}\text { Sprague Dawley rats } \\
\text { model of TBI } \\
\text { (Induction of lateral } \\
\text { fluid percussion) }\end{array}$ & $\begin{array}{l}\text { PI3K/Akt1 mediated by } \\
\text { GPER } \\
\text { IL-1 } \beta \text {, IL-6, TNF, TGF- } \beta \\
\text { caspase-3 } \\
\text { GFAP }\end{array}$ & $\begin{array}{l}\text { Decreases neuronal degeneration, astrogliosis, } \\
\text { programmed cell death and the cleavage of } \\
\text { caspase- } 3 \text { in the cortical pericontusional zone, } \\
\text { enhances ER } a \text { expression } \\
\text { Regulation of mitochondrial calcium } \\
\text { sequestration } \\
\text { Reduce oxidative stress and levels of } \\
\text { proinflammatory cytokines }\end{array}$ & $\begin{array}{l}{[143,228,260,} \\
261]\end{array}$ \\
\hline & Estradiol & Rodent model of TBI & estrogen receptors & $\begin{array}{l}\text { Decreases cortical reactive astrogliosis and } \\
\text { reduce the extent of injury }\end{array}$ & {$[123]$} \\
\hline \multirow[t]{3}{*}{$\begin{array}{l}\text { Synthetic } \\
\text { estrogens }\end{array}$} & $\begin{array}{l}\text { Tibolone } \\
(10 \mathrm{nM})\end{array}$ & $\begin{array}{l}\text { Human Astrocyte cell } \\
\text { model and microglial } \\
\text { cells subjected to } \\
\text { inflammatory stimuli }\end{array}$ & $\begin{array}{l}\text { Neuroglobin and NF- } \kappa \mathrm{B} \\
\text { mediated by } \mathrm{ER} \beta\end{array}$ & $\begin{array}{l}\text { Decreases cell death, nuclear fragmentation, } \\
\text { superoxide ion production, mitochondrial } \\
\text { membrane potential and cytoplasmic calcium } \\
\text { concentration }\end{array}$ & $\begin{array}{l}{[120,121,130,} \\
131]\end{array}$ \\
\hline & $\begin{array}{l}\text { Tibolone } \\
(1 \mathrm{mg} / \mathrm{k})\end{array}$ & $\begin{array}{l}\text { Rats exposed to brain } \\
\text { oxidative stress }\end{array}$ & $\begin{array}{l}\text { Increased SOD through the } \\
\text { ER }\end{array}$ & $\begin{array}{l}\text { Reduces the formation of ROS and the } \\
\text { oxidation of lipids and proteins in CNS } \\
\text { Increased the overall antioxidant capacity in } \\
\text { the cerebral cortex and hippocampus } \\
\text { Prevents cognitive deficits in short- and long- } \\
\text { term memory and enhances cognitive } \\
\text { performance }\end{array}$ & {$[262-264]$} \\
\hline & $\begin{array}{l}\text { Tibolone } \\
(2.5 \mathrm{mg} / \text { day })\end{array}$ & $\begin{array}{l}\text { Women who for } 10 \\
\text { years had been taking } \\
\text { tibolone }\end{array}$ & ND & Improves the semantic memory & {$[265]$} \\
\hline \multirow[t]{6}{*}{ SERMS } & $\begin{array}{l}\text { Raloxifene } \\
(<10 \mu \mathrm{M})\end{array}$ & $\begin{array}{l}\text { Primary cultures of } \\
\text { Astrocytes }\end{array}$ & $\begin{array}{l}\text { Inhibitory action on CCL } 20 \\
\text { expression and NF- } \kappa B \\
\text { ER } \alpha\end{array}$ & $\begin{array}{l}\text { Reduction of neuroinflammation and reactive } \\
\text { astrogliosis } \\
\text { Reduces neuronal injury and increase anti- } \\
\text { apoptotic caspase-3-independent actions }\end{array}$ & {$[172,173,225]$} \\
\hline & $\begin{array}{l}\text { Raloxifene } \\
(1 \mu \mathrm{M})\end{array}$ & & $\begin{array}{l}\text { ERK, EGFR, and CREB } \\
\text { NF- } \kappa B, \text { MAPK and PI3K } \\
\text { mediated by ER- } \alpha, \text { ER- } \beta \text {, } \\
\text { and GPR } 30\end{array}$ & $\begin{array}{l}\text { Exerts neuroprotection through increased } \\
\text { glutamate uptake and expression of GLT1 } \\
\text { mRNA and protein levels in astrocytes }\end{array}$ & $\begin{array}{l}{[185,196,197,} \\
266]\end{array}$ \\
\hline & $\begin{array}{l}\text { Tamoxifene } \\
(1 \mu \mathrm{M})\end{array}$ & & $\begin{array}{l}\text { TGF- } \alpha \text { signaling, CREB, } \\
\text { NF- } \kappa \text { B and PKA mediated by } \\
\text { ER- } \alpha, \text { ER- } \beta \text {, and GPR } 30\end{array}$ & $\begin{array}{l}\text { Neuroprotection by enhanced of astrocytic } \\
\text { GLT-1 expression }\end{array}$ & {$[196,197,267]$} \\
\hline & $\begin{array}{l}\text { Raloxifene } \\
(3.0 \mathrm{mg} / \mathrm{kg})\end{array}$ & $\begin{array}{l}\text { Rodent model of TBI } \\
\text { (bilateral cortical } \\
\text { contusion) injury }\end{array}$ & MAPK/ERK1/2 & $\begin{array}{l}\text { Reduces sensorimotor and working memory } \\
\text { deficits following TBI } \\
\text { Enhances neurogenesis and spine density }\end{array}$ & $\begin{array}{l}{[12,133,268,} \\
269]\end{array}$ \\
\hline & $\begin{array}{l}\text { Tamoxifen } \\
(1 \mathrm{mg} / \mathrm{kg})\end{array}$ & Rodent model of TBI & $\begin{array}{l}\uparrow \mathrm{P} \text {-ERK } 1 / 2, \mathrm{Bcl} 2 \text { and } \downarrow \mathrm{Bax} \\
\text { mediated by ER- } \alpha\end{array}$ & $\begin{array}{l}\text { Improved motor function, increased spared } \\
\text { tissue, reduced TBI-induced cerebral } \\
\text { infarction volume and Decrease the formation } \\
\text { of ROS, cell apoptosis and neuronal loss }\end{array}$ & {$[174,270]$} \\
\hline & $\begin{array}{l}\text { Raloxifen and } \\
\text { Tamoxifen } \\
(1 \mathrm{mg} / \mathrm{kg})\end{array}$ & & ND & $\begin{array}{l}\text { Decrease the number of reactive astrocytes } \\
\text { after TBI } \\
\text { Decreases microglial activation and } \\
\text { production of pro-inflammatory cytokines }\end{array}$ & $\begin{array}{l}{[48,123,170,} \\
271]\end{array}$ \\
\hline
\end{tabular}


Table 4 (continued)

\begin{tabular}{|c|c|c|c|c|c|}
\hline EC & Compound & Model & Mechanisms & Protective effect & References \\
\hline \multirow[t]{3}{*}{$\begin{array}{l}\text { Phyto- } \\
\text { estrogens }\end{array}$} & $\begin{array}{l}\text { Resveratrol } \\
(100 \mathrm{mg} / \mathrm{kg})\end{array}$ & Wistar Albino rats & $\begin{array}{l}\text { Antioxidant activity by } \\
\text { Xanthine oxidase, } \\
\text { glutathione, lipid } \\
\text { peroxidation }\end{array}$ & $\begin{array}{l}\text { Improved locomotor activity, memory } \\
\text { maintenance, decreased anxiety, avoid cell } \\
\text { death } \\
\text { Reduced MDA, XO and NO levels, increased } \\
\text { GSH level }\end{array}$ & {$[178,217]$} \\
\hline & $\begin{array}{l}\text { Genistein } \\
(15 \mathrm{mg} / \mathrm{kg})\end{array}$ & Male Wistar rats & $\begin{array}{l}\text { Antioxidant and anti- } \\
\text { inflammatory mechanisms } \\
\text { by ERs and Glucocorticoid } \\
\text { receptor }\end{array}$ & $\begin{array}{l}\text { Reversal of brain edema formation, restores } \\
\text { BBB disruption, decreases ICP levels, } \\
\text { recovered motor function } \\
\text { Prevented the excessive activation of microglia }\end{array}$ & {$[159,272]$} \\
\hline & $\begin{array}{l}\text { Puerarin } \\
(200 \mathrm{mg} / \mathrm{kg})\end{array}$ & Sprague-Dawley rats & $\begin{array}{l}\text { Antioxidant activity, } \\
\text { Regulation of apoptotic } \\
\text { molecules by PI3K-Akt }\end{array}$ & $\begin{array}{l}\text { Reduced TBI-induced neuronal } \\
\text { degeneration, increase the Akt } \\
\text { phosphorylation, improve endogenous } \\
\text { antioxidant defense, ameliorat the cellular } \\
\text { membrane damage, decreases } \\
\text { neuroinflammation, restores the redox } \\
\text { balance }\end{array}$ & [179] \\
\hline
\end{tabular}

IL, Interleukin; TGF- $\beta$, Transforming growth factor-beta; PI3K/Akt, Phosphatidylinositol 3-kinase pathway; GFAP, Glial Fibrillary Acidic Protein; NF$\kappa B$, Nuclear factor kB; SOD, Superoxide Dismutase; CCL20, C-C motif chemokine ligand 20; EGFR, epidermal growth factor receptor; CREB, cAMP response element-binding.

astrogliosis and glial scar formation after TBI $[123,169-$ 171, 199-201]. After spinal cord injury, tamoxifen has been shown to first increase astrogliosis at day 2 after injury and then gradually decrease astrogliosis [202]. This suggests that tamoxifen may accelerate the process of astrogliosis, increasing reactive astrocytes in the acute injury phase, where astrocytes may release trophic factors to protect neurons, and decrease reactive astrocytes in the chronic injury phase.

\section{Regulation of Excitotoxicity}

Glutamate transporters are related to excitotoxic brain injury and neurodegenerative diseases. Excitotoxic damage is produced by a dysregulation of astrocytic glutamate carriers, such as glutamate transporter-1, which is responsible for absorbing the majority of glutamate from the synaptic cleft, maintaining optimal glutamate levels [203]. Excessive extracellular glutamate leads to a dysregulation in calcium, sodium and potassium fluxes, which may open the mitochondrial permeabilty transition pore. The opening of the mitochondrial pore could liberate ROS and proteins that may lead to apoptosis $[203,204]$.

Estradiol, other several estrogenic compounds and genistein have been shown to decrease excitotoxic damage in the brain in vivo [122, 126, 205-209]. Estradiol and tamoxifen increase the expression of the glutamate transporters glutamate aspartate transporter (GLAST) and glutamate transporter-1, increasing glutamate uptake by astrocytes [181, 196, 197]. This estrogenic action is mediated by ERs, including G-protein coupled ER, and the PI3K and Mitogen-activated protein kinase signalling pathways $[185,196,197,210]$. The phytoestrogen resveratrol increases glutamate uptake and glutamine synthetase activity in primary cortical astrocytes [211]. This action may be involved in the protective actions of phytoestrogens against excitotoxic damage $[159,211,212]$.

\section{Regulation of Oxidative Stress}

Different estrogenic compounds, such as tamoxifen, hydroxytamoxifen, genistein and raloxifene, have been shown to control oxidative stress in the brain tissue [155, $159,213,214]$. This action is exerted by increasing the activities of several detoxifying enzymes such as superoxide dismutase, catalase and glutathione peroxidase $[156,159,212,215]$. In astrocytes, estrogenic compounds modulate mitochondrial gene expression, increase clearance of ROS and decrease the loss of antioxidant glutathione $[10,179]$. In an in vitro model of ischemia (oxy- 
gen-glucose deprivation/reperfusion) in primary astrocytes $17 \beta$-estradiol and tibolone decreased the production of ROS, recovered the mitochondrial membrane potential and ATP production and decreased cell death induced by mitochondrial dysfunction [216]. The actions of estrogenic compounds on oxidative stress after brain injury may be associated with the reduction in edema formation [217]. For instance, resveratrol decreases lipid peroxidation in the trauma zone and it is known that lipid peroxidation contributes to ischemia and cerebral edema [160,217], and worsens the prognosis of patients with TBI. Additionally, genistein and daidzein increase iron transport, as a result of oxidative stress [155], protect DNA and mitochondrial function [156], and exert anti-inflammatory effect by inducing the expression of antioxidant enzymes such as thioredoxin, MnSOD, iNOS and COXs [157] and PPARs in different astrocytic cell lines [158].

Regulation of Mitochondrial Function

An important neuroprotective mechanism of estrogenic compounds is the regulation of mitochondrial function [218-220]. Mitochondria are vital for the maintenance and homeostasis of different brain cells and their dysfunction has been associated with several neurological disorders [221, 222]. Some investigations suggest that mitochondria can be regulated by estrogenic compounds and their interactions with ERs. For example, it has been demonstrated that ER $\beta$ is located in the mitochondria of various brain cells including astrocytes [223]. Therefore, it has been proposed that the neuroprotective actions of estrogenic compounds linked to mitochondria are mediated by ER $\beta$ [223]. ER $\beta$ located in the mitochondria may prevent mitochondrial expression of apoptotic molecules and regulate the function and production of other proteins involved in the reduction of ROS [219].

Regulation of Neuroinflammation

Astrocytes and microglia play an important role in inflammatory responses after TBI, as these cells release growth factors, cytokines and chemokines. These molecules could act as modulators for the beginning and progression of post-traumatic inflammation. Thus, the participation of these cells may be causing extra cell death and neurological damage $[8,164,224]$. Estrogenic compounds, like estradiol, SERMs and phytoestrogens, act on astrocytes and microglial cells reducing neuroinflammation through a decrease in the expression of IL- $1 \beta$, IL- 6 , tumour necrosis factor (TNF- $\alpha$ ) and (TNF- $\beta$ ) $[131,225-$
228]. The anti-inflammatory actions of estrogenic compounds on these cells begin with the activation of signalling pathways (Mitogen-activated protein kinase, PI3K, and Akt), which in turn control the activity of transcription factors such as cAMP response element-binding and NF- $\mathrm{B}[119,225]$, a powerful transcriptional regulator of several inflammatory genes [224].

\section{Concluding Remarks}

It is clear that the role of astrocytes on TBI is dependent upon the stage of the pathological mechanism. This is especially important when designing potential protective strategies aimed at controlling reactive astrogliosis and astrocytic double-edged functions. This review highlights the neuroprotective actions of estrogenic compounds and their action on astrocytes in the context of TBI. The response of the wounded nervous tissue to estrogenic compounds is contingent on the interface of multiple cell types, like microglia, tanycytes and astrocytes. One of the most important cells is astrocytes that play vital roles in TBI and in post-TBI synaptic plasticity. This response is determined by specific signalling mechanisms and depends on the nature and severity of tissue damage. Besides, astrocytes have shown to be targets of estrogen and estrogenic compounds and are postulated to have a key role in estrogen-mediated protection of the brain. These compounds have a promising potential as a target for therapeutic approaches for the prevention of cognition decline and neurodegeneration caused by brain trauma. However, further studies are needed to deepen the mechanisms of action of estrogenic compounds in astrocytes and how they trigger a neuroprotective response in TBI.

\section{Acknowledgement}

This work is in part funded by Colciencias grant (Contract No. 824-2017) to G.E.B.

\section{Statement of Ethics}

The authors have no ethical conflicts to disclose.

\section{Disclosure Statement}

The authors declare no conflicts of interest. 


\section{References}

1 Prins M, Greco T, Alexander D, Giza CC. The pathophysiology of traumatic brain injury at a glance. Dis Model Mech. 2013 Nov;6(6): 1307-15.

2 Barreto GE, Gonzalez J, Torres Y, Morales L. Astrocytic-neuronal crosstalk: implications for neuroprotection from brain injury. Neurosci Res. 2011 Oct;71(2):107-13.

3 Heegaard W, Biros M. Traumatic brain injury. Emerg Med Clin North Am. 2007 Aug; 25(3):655-78.

4 Lovasik D, Kerr ME, Alexander S. Traumatic brain injury research: a review of clinical studies. Crit Care Nurs Q. 2001 Feb;23(4):24-41.

5 Santiago LA, Oh BC, Dash PK, Holcomb JB, Wade CE. A clinical comparison of penetrating and blunt traumatic brain injuries. Brain Inj. 2012;26(2):107-25.

6 Giustini A, Pistarini C, Pisoni C. Traumatic and nontraumatic brain injury. Handb Clin Neurol. 2013;110:401-9.

7 Burda JE, Bernstein AM, Sofroniew MV. Astrocyte roles in traumatic brain injury. Exp Neurol. 2016 Jan;275 Pt 3:305-15.

8 Arevalo MA, Santos-Galindo M, Lagunas N, Azcoitia I, Garcia-Segura LM. Selective estrogen receptor modulators as brain therapeutic agents. J Mol Endocrinol. 2011 Jan;46(1):R1-

9 Kim JV, Dustin ML. Innate response to focal necrotic injury inside the blood-brain barrier. J Immunol. 2006 Oct;177(8):5269-77.

10 Zhao L, O’Neill K, Diaz Brinton R. Selective estrogen receptor modulators (SERMs) for the brain: current status and remaining challenges for developing NeuroSERMs. Brain Res Brain Res Rev. 2005 Nov;49(3):472-93.

11 de Medeiros AR, Lamas AZ, Caliman IF, Dalpiaz PL, Firmes LB, de Abreu GR, et al. Tibolone has anti-inflammatory effects in estrogen-deficient female rats on the natriuretic peptide system and TNF-alpha. Regul Pept. 2012 Nov; $179(1-3): 55-60$.

12 Khan MM, Wakade C, de Sevilla L, Brann DW. Selective estrogen receptor modulators (SERMs) enhance neurogenesis and spine density following focal cerebral ischemia. J Steroid Biochem Mol Biol. 2015 Feb;146:3847.

13 Dhandapani K, Brann D. Neuroprotective effects of estrogen and tamoxifen in vitro: a facilitative role for glia? Endocrine. 2003 Jun 21(1):59-66.

14 Acaz-Fonseca E, Sanchez-Gonzalez R, Azcoitia I, Arevalo MA, Garcia-Segura LM. Role of astrocytes in the neuroprotective actions of $17 \beta$-estradiol and selective estrogen receptor modulators. Mol Cell Endocrinol. 2014 May; 389(1-2):48-57.

15 Arevalo MA, Azcoitia I, Garcia-Segura LM The neuroprotective actions of oestradiol and oestrogen receptors. Nat Rev Neurosci. 2015 Jan;16(1):17-29.
16 Escobedo LV, Habboushe J, Kaafarani H, Velmahos G, Shah K, Lee J. Traumatic brain injury: A case-based review. World J Emerg Med. 2013;4(4):252-9.

17 Dinsmore J. Traumatic brain injury: an evidence-based review of management. Contin Educ Anaesth Crit Care Pain. 2013;13(6): 189-95.

18 Andersen LW, Mackenhauer J, Roberts JC, Berg KM, Cocchi MN, Donnino MW. Etiology and therapeutic approach to elevated lactate levels. Mayo Clin Proc. 2013 Oct;88(10): 1127-40.

19 Yousefzadeh-Chabok S, Dehnadi Moghaddam A, Kazemnejad-Leili E, Saneei Z, Hosseinpour M, Kouchakinejad-Eramsadati L, et al. The Relationship Between Serum Levels of Interleukins 6, 8, 10 and Clinical Outcome in Patients With Severe Traumatic Brain Injury. Arch Trauma Res. 2015 Feb;4(1):e1835718357.

20 Ray SK, Dixon CE, Banik NL. Molecular mechanisms in the pathogenesis of traumatic brain injury. Histol Histopathol. 2002 Oct; 17(4):1137-52.

21 Downard C, Hulka F, Mullins RJ, Piatt J, Chesnut R, Quint P, et al. Relationship of cerebral perfusion pressure and survival in pediatric brain-injured patients. J Trauma. 2000 Oct;49(4):654-8.

22 Saatman KE, Duhaime AC, Bullock R, Maas AI, Valadka A, Manley GT; Workshop Scientific Team and Advisory Panel Members. Classification of traumatic brain injury for targeted therapies. J Neurotrauma. 2008 Jul; 25(7):719-38.

23 Greve MW, Zink BJ. Pathophysiology of traumatic brain injury. Mt Sinai J Med. 2009 Apr; 76(2):97-104

24 Graham DI, Gennarelli TA, McIntosh TK. Trauma. In: Graham DI, editor. Greenfield's Neuropathology, L.P.L. London: Arnold Publishers; 2002. pp. 823-98

25 Donkin JJ, Vink R. Mechanisms of cerebral edema in traumatic brain injury: therapeutic developments. Curr Opin Neurol. 2010 Jun; 23(3):293-9.

26 Cook LG, Chapman SB, Levin HS. Self-regulation abilities in children with severe traumatic brain injury: a preliminary investigation of naturalistic action. NeuroRehabilitation. 2008;23(6):467-75.

27 Molaie AM, Maguire J. Neuroendocrine Abnormalities Following Traumatic Brain Injury: An Important Contributor to Neuropsychiatric Sequelae. Front Endocrinol (Lausanne). 2018 Apr;9:176.

28 Osterstock G, El Yandouzi T, Romanò N, Carmignac D, Langlet F, Coutry N, et al. Sustained alterations of hypothalamic tanycytes during posttraumatic hypopituitarism in male mice. Endocrinology. 2014 May;155(5): 1887-98.
29 Mullier A, Bouret SG, Prevot V, Dehouck B. Differential distribution of tight junction proteins suggests a role for tanycytes in bloodhypothalamus barrier regulation in the adult mouse brain. J Comp Neurol. 2010 Apr 518(7):943-62.

30 Prevot V, Dehouck B, Sharif A, Ciofi P, Giacobini P, Clasadonte J. The Versatile Tanycyte: A Hypothalamic Integrator of Reproduction and Energy Metabolism. Endocr Rev. 2018 Jun;39(3):333-68.

31 Stiefel MF, Tomita Y, Marmarou A. Secondary ischemia impairing the restoration of ion homeostasis following traumatic brain injury. J Neurosurg. 2005 Oct;103(4):707-14.

32 Floyd CL, Gorin FA, Lyeth BG. Mechanical strain injury increases intracellular sodium and reverses $\mathrm{Na}+/ \mathrm{Ca} 2+$ exchange in cortical astrocytes. Glia. 2005 Jul;51(1):35-46.

33 Yi JH, Hazell AS. Excitotoxic mechanisms and the role of astrocytic glutamate transporters in traumatic brain injury. Neurochem Int. 2006 Apr;48(5):394-403.

34 DeWitt DS, Prough DS. Traumatic cerebral vascular injury: the effects of concussive brain injury on the cerebral vasculature. $J$ Neurotrauma. 2003 Sep;20(9):795-825.

35 Choi DW. Ischemia-induced neuronal apoptosis. Curr Opin Neurobiol. 1996 Oct;6(5): $667-72$.

36 Eldadah BA, Faden AI. Caspase pathways, neuronal apoptosis, and CNS injury. J Neurotrauma. 2000 Oct; 17(10):811-29.

37 Werner C, Engelhard K. Pathophysiology of traumatic brain injury. Br J Anaesth. 2007 Jul; 99(1):4-9.

38 Mattson MP, Magnus T. Ageing and neuronal vulnerability. Nat Rev Neurosci. 2006 Apr; 7(4):278-94.

39 Chen Y, Swanson RA. Astrocytes and brain injury. J Cereb Blood Flow Metab. 2003 Feb; 23(2):137-49.

40 Bayir H, Kagan VE, Borisenko GG, Tyurina YY, Janesko KL, Vagni VA, et al. Enhanced oxidative stress in iNOS-deficient mice after traumatic brain injury: support for a neuroprotective role of iNOS. J Cereb Blood Flow Metab. 2005 Jun;25(6):673-84.

41 Palmer AM, Marion DW, Botscheller ML, Swedlow PE, Styren SD, DeKosky ST. Traumatic brain injury-induced excitotoxicity assessed in a controlled cortical impact model. J Neurochem. 1993 Dec;61(6):2015-24.

42 Toklu H, Tumer N. Oxidative Stress, Brain Edema, Blood-Brain Barrier Permeability, and Autonomic Dysfunction from Traumatic Brain Injury. In: Kobeissy FH, editor. Brain Neurotrauma: Molecular, Neuropsychological, and Rehabilitation Aspects. Boca Raton (FL): CRC Press/Taylor \& Francis; 2015. Chapter 5.

43 DeWitt DS, Prough DS. Blast-induced brain injury and posttraumatic hypotension and hypoxemia. J Neurotrauma. 2009 Jun;26(6): $877-87$. 
44 Vuceljić M, Zunić G, Romić P, Jevtić M. Relation between both oxidative and metabolicosmotic cell damages and initial injury severity in bombing casualties. Vojnosanit Pregl. 2006 Jun;63(6):545-51.

45 Raps SP, Lai JC, Hertz L, Cooper AJ. Glutathione is present in high concentrations in cultured astrocytes but not in cultured neurons. Brain Res. 1989 Jul;493(2):398-401.

46 Wang J, Ma JH, Giffard RG. Overexpression of copper/zinc superoxide dismutase decreases ischemia-like astrocyte injury. Free Radic Biol Med. 2005 Apr;38(8):1112-8.

47 Cabezas R, Avila M, Gonzalez J, El-Bachá RS, Báez E, García-Segura LM, et al. Astrocytic modulation of blood brain barrier: perspectives on Parkinson's disease. Front Cell Neurosci. 2014 Aug;8(AUG):211-211.

48 Iglesias J, Morales L, Barreto GE. Metabolic and Inflammatory Adaptation of Reactive Astrocytes: Role of PPARs. Mol Neurobiol. 2017 May;54(4):2518-2538.

49 Posada-Duque RA, Barreto GE, Cardona-Gomez GP. Protection after stroke: cellular effectors of neurovascular unit integrity. Front Cell Neurosci. 2014 Aug;8(August):231-231.

50 Suzumura A. Neuron-microglia interaction in neuroinflammation. Curr Protein Pept Sci. 2013 Feb;14(1):16-20.

51 Verkhratsky A, Butt A. Glial Physiology and Pathophysiology. John Wiley \& Sons, Ltd.; 2013.https://doi.org/10.1002/9781118402061.

52 Parpura V, Heneka MT, Montana V, Oliet SH, Schousboe A, Haydon PG, et al. Glial cells in (patho)physiology. J Neurochem. 2012 Apr;121(1):4-27.

53 Gavillet M, Allaman I, Magistretti PJ. Modulation of astrocytic metabolic phenotype by proinflammatory cytokines. Glia. $2008 \mathrm{Jul}$; 56(9):975-89.

54 Volterra A, Meldolesi J. Astrocytes, from brain glue to communication elements: the revolution continues. Nat Rev Neurosci. 2005 Aug;6(8):626-40.

55 Navarrete M, Araque A. Basal synaptic transmission: astrocytes rule! Cell. 2011 Sep; 146(5):675-7.

56 Perea G, Navarrete M, Araque A. Tripartite synapses: astrocytes process and control synaptic information. Trends Neurosci. 2009 Aug;32(8):421-31.

57 Pérez-Alvarez A, Araque A. Astrocyte-neuron interaction at tripartite synapses. Curr Drug Targets. 2013 Oct;14(11):1220-4.

58 Liberto CM, Albrecht PJ, Herx LM, Yong VW, Levison SW. Pro-regenerative properties of cytokine-activated astrocytes. J Neurochem. 2004 Jun;89(5):1092-100.

59 Parpura V, Scemes E, Spray DC. Mechanisms of glutamate release from astrocytes: gap junction "hemichannels", purinergic receptors and exocytotic release. Neurochem Int. 2004 Jul-Aug;45(2-3):259-64.

60 Volterra A, Steinhäuser C. Glial modulation of synaptic transmission in the hippocampus. Glia. 2004 Aug;47(3):249-57.
61 Sofroniew MV, Vinters HV. Astrocytes: biology and pathology. Acta Neuropathol. 2010 Jan;119(1):7-35.

62 Garcia-Segura LM, Melcangi RC. Steroids and glial cell function. Glia. 2006 Nov;54(6): 485-98.

63 Fuente-Martin E, Garcia-Caceres C, Morselli E, Clegg DJ, Chowen JA, Finan B, et al. Estrogen, astrocytes and the neuroendocrine control of metabolism. Rev Endocr Metab Disord. 2013 Dec;14(4):331-8.

64 Micevych P, Bondar G, Kuo J. Estrogen actions on neuroendocrine glia. Neuroendocrinology. 2010;91(3):211-22.

65 Wicher G, Norlin M. Estrogen-mediated regulation of steroid metabolism in rat glial cells; effects on neurosteroid levels via regulation of CYP7B1-mediated catalysis. J Steroid Biochem Mol Biol. 2015 Jan;145:21-7.

66 Bolborea M, Dale N. Hypothalamic tanycytes: potential roles in the control of feeding and energy balance. Trends Neurosci. 2013 Feb; 36(2):91-100.

67 Rodríguez EM, Blázquez JL, Pastor FE, Peláez B, Peña P, Peruzzo B, et al. Hypothalamic tanycytes: a key component of brain-endocrine interaction. Int Rev Cytol. 2005;247:89-164.

68 Duncan SR. Estrogen Effects on Traumatic Brain Injury. 1st ed. 2018.

69 Gorina R, Font-Nieves M, Márquez-Kisinousky L, Santalucia T, Planas AM. Astrocyte TLR4 activation induces a proinflammatory environment through the interplay between MyD88-dependent NFkB signaling, MAPK, and Jak1/Stat1 pathways. Glia. 2011 Feb;59(2):242-55.

70 Paintlia MK, Paintlia AS, Singh AK, Singh I. S-nitrosoglutathione induces ciliary neurotrophic factor expression in astrocytes, which has implications to protect the central nervous system under pathological conditions. J Biol Chem. 2013 Feb;288(6):3831-43.

71 Pekny M, Johansson CB, Eliasson C, Stakeberg J, Wallén A, Perlmann T, et al. Abnormal reaction to central nervous system injury in mice lacking glial fibrillary acidic protein and vimentin. J Cell Biol. 1999 May;145(3):503-14.

72 Pekny M, Nilsson M. Astrocyte activation and reactive gliosis. Glia. 2005 Jun;50(4):427-34.

73 Silver J, Miller JH. Regeneration beyond the glial scar. Nat Rev Neurosci. 2004 Feb;5(2): 146-56.

74 Zamanian JL, Xu L, Foo LC, Nouri N, Zhou L, Giffard RG, et al. Genomic analysis of reactive astrogliosis. J Neurosci. 2012 May;32(18): 6391-410.

75 Brambilla R, Bracchi-Ricard V, Hu WH, Frydel B, Bramwell A, Karmally S, et al. Inhibition of astroglial nuclear factor kappaB reduces inflammation and improves functional recovery after spinal cord injury. J Exp Med. 2005 Jul;202(1):145-56.

76 Herrmann JE, Imura T, Song B, Qi J, Ao Y, Nguyen TK, et al. STAT3 is a critical regulator of astrogliosis and scar formation after spinal cord injury. J Neurosci. 2008 Jul;28(28):723143.
77 Okada S, Nakamura M, Katoh H, Miyao T, Shimazaki T, Ishii K, et al. Conditional ablation of Stat 3 or Socs 3 discloses a dual role for reactive astrocytes after spinal cord injury. Nat Med. 2006 Jul;12(7):829-34.

78 Wanner IB, Anderson MA, Song B, Levine J, Fernandez A, Gray-Thompson Z, et al. Glial scar borders are formed by newly proliferated, elongated astrocytes that interact to corral inflammatory and fibrotic cells via STAT3-dependent mechanisms after spinal cord injury. J Neurosci. 2013 Jul;33(31):12870-86.

79 Eng LF, Ghirnikar RS. GFAP and astrogliosis. Brain Pathol. 1994 Jul;4(3):229-37.

80 Hamby ME, Sofroniew MV. Reactive astrocytes as therapeutic targets for CNS disorders. Neurotherapeutics. 2010 Oct;7(4):494-506.

81 Mucke L, Eddleston M. Astrocytes in infectious and immune-mediated diseases of the central nervous system. FASEB J. 1993 Oct; 7(13):1226-32.

82 Pekny M, Pekna M. Astrocyte reactivity and reactive astrogliosis: costs and benefits. Physiol Rev. 2014 Oct; 94(4):1077-98.

83 Hernandez MR, Agapova OA, Yang P, Salvador-Silva M, Ricard CS, Aoi S. Differential gene expression in astrocytes from human normal and glaucomatous optic nerve head analyzed by cDNA microarray. Glia. 2002 Apr;38(1):45-64.

84 Sofroniew MV. Molecular dissection of reactive astrogliosis and glial scar formation. Trends Neurosci. 2009 Dec;32(12):638-47.

85 Wilhelmsson U, Bushong EA, Price DL, Smarr BL, Phung V, Terada M, et al. Redefining the concept of reactive astrocytes as cells that remain within their unique domains upon reaction to injury. Proc Natl Acad Sci USA. 2006 Nov;103(46):17513-8.

86 McKeon RJ, Schreiber RC, Rudge JS, Silver J. Reduction of neurite outgrowth in a model of glial scarring following CNS injury is correlated with the expression of inhibitory molecules on reactive astrocytes. J Neurosci. 1991 Nov;11(11):3398-411.

87 Bush TG, Puvanachandra N, Horner $\mathrm{CH}$, Polito A, Ostenfeld T, Svendsen CN, et al. Leukocyte infiltration, neuronal degeneration, and neurite outgrowth after ablation of scar-forming, reactive astrocytes in adult transgenic mice. Neuron. 1999 Jun;23(2): 297-308

88 Faulkner JR, Herrmann JE, Woo MJ, Tansey KE, Doan NB, Sofroniew MV. Reactive astrocytes protect tissue and preserve function after spinal cord injury. J Neurosci. 2004 Mar; 24(9):2143-55.

89 Voskuhl RR, Peterson RS, Song B, Ao Y, Morales LB, Tiwari-Woodruff $S$, et al. Reactive astrocytes form scar-like perivascular barriers to leukocytes during adaptive immune inflammation of the CNS. J Neurosci. 2009 Sep; 29(37):11511-22. 
90 Garcia-Segura LM, Wozniak A, Azcoitia I, Rodriguez JR, Hutchison RE, Hutchison JB. Aromatase expression by astrocytes after brain injury: implications for local estrogen formation in brain repair. Neuroscience. 1999 Mar;89(2):567-78.

91 Alilain WJ, Horn KP, Hu H, Dick TE, Silver J. Functional regeneration of respiratory pathways after spinal cord injury. Nature. 2011 Jul;475(7355):196-200.

92 Bradbury EJ, Moon LD, Popat RJ, King VR, Bennett GS, Patel PN, et al. Chondroitinase $\mathrm{ABC}$ promotes functional recovery after spinal cord injury. Nature. 2002 Apr;416(6881): 636-40.

93 Fitch MT, Silver J. CNS injury, glial scars, and inflammation: inhibitory extracellular matrices and regeneration failure. Exp Neurol. 2008 Feb;209(2):294-301.

94 Burda JE, Sofroniew MV. Reactive gliosis and the multicellular response to CNS damage and disease. Neuron. 2014 Jan;81(2): 229-48.

95 Sofroniew MV. Astrogliosis. Cold Spring Harb Perspect Biol. 2014 Nov;7(2):a020420.

96 Zador Z, Stiver S, Wang V, Manley GT. Role of aquaporin-4 in cerebral edema and stroke. Handb Exp Pharmacol. 2009;190(190):15970.

97 Argaw AT, Gurfein BT, Zhang Y, Zameer A, John GR. VEGF-mediated disruption of endothelial CLN-5 promotes blood-brain barrier breakdown. Proc Natl Acad Sci USA. 2009 Feb;106(6):1977-82.

98 Bell RD, Winkler EA, Singh I, Sagare AP, Deane R, Wu Z, et al. Apolipoprotein E controls cerebrovascular integrity via cyclophilin A. Nature. 2012 May;485(7399): 512-6.

99 De Keyser J, Mostert JP, Koch MW. Dysfunctional astrocytes as key players in the pathogenesis of central nervous system disorders. J Neurol Sci. 2008 Apr;267(1-2):3-16.

100 Gris P, Tighe A, Levin D, Sharma R, Brown A. Transcriptional regulation of scar gene expression in primary astrocytes. Glia. 2007 Aug;55(11):1145-55.

101 Colodner KJ, Montana RA, Anthony DC, Folkerth RD, De Girolami U, Feany MB. Proliferative potential of human astrocytes. J Neuropathol Exp Neurol. 2005 Feb;64(2): 163-9.

102 Horner PJ, Power AE, Kempermann G, Kuhn HG, Palmer TD, Winkler J, et al. Proliferation and differentiation of progenitor cells throughout the intact adult rat spinal cord. J Neurosci. 2000 Mar;20(6): 2218-28.

103 Norton WT, Aquino DA, Hozumi I, Chiu FC, Brosnan CF. Quantitative aspects of reactive gliosis: a review. Neurochem Res. 1992 Sep; 17(9):877-85.

104 Gadea A, Schinelli S, Gallo V. Endothelin-1 regulates astrocyte proliferation and reactive gliosis via a JNK/c-Jun signaling pathway. J Neurosci. 2008 Mar;28(10):2394-408.
105 Levison SW, Jiang FJ, Stoltzfus OK, Ducceschi MH. IL-6-type cytokines enhance epidermal growth factor-stimulated astrocyte proliferation. Glia. 2000 Dec;32(3):328-37.

106 Neary JT, Zimmermann H. Trophic functions of nucleotides in the central nervous system. Trends Neurosci. 2009 Apr;32(4): 189-98.

107 Buffo A, Rite I, Tripathi P, Lepier A, Colak $\mathrm{D}$, Horn AP, et al. Origin and progeny of reactive gliosis: A source of multipotent cells in the injured brain. Proc Natl Acad Sci USA. 2008 Mar; 105(9):3581-6.

108 Magnus T, Carmen J, Deleon J, Xue H, Pardo AC, Lepore AC, et al. Adult glial precursor proliferation in mutant SOD1G93A mice. Glia. 2008 Jan;56(2):200-8.

109 Carlén M, Meletis K, Göritz C, Darsalia V, Evergren E, Tanigaki K, et al. Forebrain ependymal cells are Notch-dependent and generate neuroblasts and astrocytes after stroke. Nat Neurosci. 2009 Mar;12(3):25967.

110 Meletis K, Barnabé-Heider F, Carlén M, Evergren E, Tomilin N, Shupliakov O, et al. Spinal cord injury reveals multilineage differentiation of ependymal cells. PLoS Biol. 2008 Jul;6(7):e182.

111 Ohab JJ, Carmichael ST. Poststroke neurogenesis: emerging principles of migration and localization of immature neurons. Neuroscientist. 2008 Aug;14(4):369-80.

112 Rothstein JD, Dykes-Hoberg M, Pardo CA, Bristol LA, Jin L, Kuncl RW, et al. Knockout of glutamate transporters reveals a major role for astroglial transport in excitotoxicity and clearance of glutamate. Neuron. 1996 Mar;16(3):675-86.

113 Swanson RA, Ying W, Kauppinen TM. Astrocyte influences on ischemic neuronal death. Curr Mol Med. 2004 Mar;4(2):193205.

114 Colangelo AM, Alberghina L, Papa M. Astrogliosis as a therapeutic target for neurodegenerative diseases. Neurosci Lett. 2014 Apr;565:59-64.

115 Drögemüller K, Helmuth U, Brunn A, Sakowicz-Burkiewicz M, Gutmann DH, Mueller $\mathrm{W}$, et al. Astrocyte gp130 expression is critical for the control of Toxoplasma encephalitis. J Immunol. 2008 Aug;181(4):2683-93.

116 Tian DS, Yu ZY, Xie MJ, Bu BT, Witte OW, Wang W. Suppression of astroglial scar formation and enhanced axonal regeneration associated with functional recovery in a spinal cord injury rat model by the cell cycle inhibitor olomoucine. J Neurosci Res. 2006 Oct;84(5):1053-63.

117 Montgomery DL. Astrocytes: form, functions, and roles in disease. Vet Pathol. 1994 Mar;31(2):145-67.

118 Acaz-Fonseca E, Avila-Rodriguez M, Garcia-Segura LM, Barreto GE. Regulation of astroglia by gonadal steroid hormones under physiological and pathological conditions. Prog Neurobiol. 2016 Sep;144:5-26.
119 Arevalo MA, Santos-Galindo M, Bellini MJ Azcoitia I, Garcia-Segura LM. Actions of estrogens on glial cells: implications for neuroprotection. Biochim Biophys Acta. 2010 Oct; 1800(10):1106-12.

120 Ávila Rodriguez M, Garcia-Segura LM, Cabezas R, Torrente D, Capani F, Gonzalez J, Barreto GE. Tibolone protects T98G cells from glucose deprivation. J Steroid Biochem Mol Biol. 2014 Oct;144 Pt B:294-303.

121 Avila-Rodriguez M, Garcia-Segura LM, Hidalgo-Lanussa O, Baez E, Gonzalez J, Barreto GE. Tibolone protects astrocytic cells from glucose deprivation through a mechanism involving estrogen receptor beta and the upregulation of neuroglobin expression. Mol Cell Endocrinol. 2016 Sep;433:35-46.

122 Azcoitia I, Moreno A, Carrero P, Palacios S, Garcia-Segura LM. Neuroprotective effects of soy phytoestrogens in the rat brain. Gynecol Endocrinol. 2006 Feb;22(2):63-9.

123 Barreto G, Santos-Galindo M, Diz-Chaves Y, Pernía O, Carrero P, Azcoitia I, et al. Selective estrogen receptor modulators decrease reactive astrogliosis in the injured brain: effects of aging and prolonged depletion of ovarian hormones. Endocrinology. 2009 Nov; 150(11):5010-5.

124 Barreto GE, Santos-Galindo M, Garcia-Segura LM. Selective estrogen receptor modulators regulate reactive microglia after penetrating brain injury. Front Aging Neurosci. 2014 Jun; 6:132.

125 Callier S, Morissette M, Grandbois M, Pélaprat D, Di Paolo T. Neuroprotective properties of 17beta-estradiol, progesterone, and raloxifene in MPTP C57Bl/6 mice. Synapse. 2001 Aug;41(2):131-8.

126 Ciriza I, Carrero P, Azcoitia I, Lundeen SG, Garcia-Segura LM. Selective estrogen receptor modulators protect hippocampal neurons from kainic acid excitotoxicity: differences with the effect of estradiol. J Neurobiol. 2004 Nov;61(2):209-21.

127 Dhandapani KM, Brann DW. Protective effects of estrogen and selective estrogen receptor modulators in the brain. Biol Reprod. 2002 Nov;67(5):1379-85.

128 DonCarlos LL, Azcoitia I, Garcia-Segura LM. Neuroprotective actions of selective estrogen receptor modulators. Psychoneuroendocrinology. 2009 Dec; 34S1: S113-S122.

129 Garcia-Ovejero D, Azcoitia I, Doncarlos LL, Melcangi RC, Garcia-Segura LM. Glia-neuron crosstalk in the neuroprotective mechanisms of sex steroid hormones. Brain Res Brain Res Rev. 2005 Apr;48(2):273-86.

130 González-Giraldo Y, Garcia-Segura LM Echeverria V, Barreto GE. Tibolone Preserves Mitochondrial Functionality and Cell Morphology in Astrocytic Cells Treated with Palmitic Acid. Mol Neurobiol. 2018 May;55(5):4453-62. 
131 Hidalgo-Lanussa O, et al. Tibolone Reduces Oxidative Damage and Inflammation in Microglia Stimulated with Palmitic Acid through Mechanisms Involving Estrogen Receptor Beta. Mol Neurobiol. 2018 Jul; 55(7):5462-5477.

132 Kimelberg HK, Jin Y, Charniga C, Feustel PJ. Neuroprotective activity of tamoxifen in permanent focal ischemia. J Neurosurg. 2003 Jul;99(1):138-42.

133 Kokiko ON, Murashov AK, Hoane MR. Administration of raloxifene reduces sensorimotor and working memory deficits following traumatic brain injury. Behav Brain Res. 2006 Jun;170(2):233-40.

134 Mehta SH, Dhandapani KM, De Sevilla LM, Webb RC, Mahesh VB, Brann DW. Tamoxifen, a selective estrogen receptor modulator, reduces ischemic damage caused by middle cerebral artery occlusion in the ovariectomized female rat. Neuroendocrinology. 2003 Jan;77(1):44-50.

135 Mickley KR, Dluzen DE. Dose-response effects of estrogen and tamoxifen upon methamphetamine-induced behavioral responses and neurotoxicity of the nigrostriatal dopaminergic system in female mice. Neuroendocrinology. 2004;79(6):305-16.

136 Rossberg MI, Murphy SJ, Traystman RJ, Hurn PD. LY353381.HCl, a selective estrogen receptor modulator, and experimental stroke. Stroke. 2000 Dec;31(12):3041-6.

137 Zhao L, O'Neill K, Brinton RD. Estrogenic agonist activity of ICI 182,780 (Faslodex) in hippocampal neurons: implications for basic science understanding of estrogen signaling and development of estrogen modulators with a dual therapeutic profile. J Pharmacol Exp Ther. 2006 Dec;319(3):1124-32.

138 Green PS, Simpkins JW. Neuroprotective effects of estrogens: potential mechanisms of action. Int J Dev Neurosci. 2000 Jul-Aug; 18(4-5):347-58.

139 Maximov PY, Lee TM, Jordan VC. The discovery and development of selective estrogen receptor modulators (SERMs) for clinical practice. Curr Clin Pharmacol. 2013 May;8(2):135-55.

140 Brinton RD. Selective estrogen receptor modulators (SERM) for the brain: recent advances and remaining challenges for developing a NeuroSERM ${ }^{\mathrm{TM}}$. Drug Dev Res. 2002; 56(3):380-92.

141 Brinton RD. Requirements of a brain selective estrogen: advances and remaining challenges for developing a NeuroSERM. J Alzheimers Dis. 2004 Dec;6(6 Suppl):S27-35.

142 López M, Tena-Sempere M. Estrogens and the control of energy homeostasis: a brain perspective. Trends Endocrinol Metab. 2015 Aug;26(8):411-21.

$143 \mathrm{Kim}$ JH, Cho HT, Kim YJ. The role of estrogen in adipose tissue metabolism: insights into glucose homeostasis regulation. Endocr J. 2014;61(11):1055-67.
144 Stanikova D, Luck T, Bae YJ, Thiery J, Ceglarek U, Engel C, et al. Increased estrogen level can be associated with depression in males. Psychoneuroendocrinology. 2018 Jan;87:196-203.

145 Engler-Chiurazzi EB, et al. Estrogens as neuroprotectants: estrogenic actions in the context of cognitive aging and brain injury. Prog Neurobiol. 2017 Oct;157:188-211.

146 Santolla MF, Lappano R, De Marco P, Pupo $M$, Vivacqua A, Sisci D, et al. G protein-coupled estrogen receptor mediates the up-regulation of fatty acid synthase induced by $17 \beta$-estradiol in cancer cells and cancer-associated fibroblasts. J Biol Chem. 2012 Dec; 287(52):43234-45.

147 Verderame M, Scudiero R. A comparative review on estrogen receptors in the reproductive male tract of non mammalian vertebrates. Steroids. 2018 Jun;134:1-8.

148 Dubal DB, Zhu H, Yu J, Rau SW, Shughrue PJ, Merchenthaler I, et al. Estrogen receptor alpha, not beta, is a critical link in estradiolmediated protection against brain injury. Proc Natl Acad Sci USA. 2001 Feb;98(4): 1952-7.

149 Born G, et al. Estrogens and Antiestrogens I. Volume 135. Springer-Verlag; 1999.

150 Blurton-Jones M, Tuszynski MH. Reactive astrocytes express estrogen receptors in the injured primate brain. J Comp Neurol. 2001 Apr;433(1):115-23.

151 García-Ovejero D, Veiga S, García-Segura LM, Doncarlos LL. Glial expression of estrogen and androgen receptors after rat brain injury. J Comp Neurol. 2002 Aug;450(3): 256-71.

152 Sirotkin AV, Harrath AH. Phytoestrogens and their effects. Eur J Pharmacol. 2014 Oct; 741:230-6.

153 Moreira AC, Silva AM, Santos MS, Sardão VA. Phytoestrogens as alternative hormone replacement therapy in menopause: what is real, what is unknown. J Steroid Biochem Mol Biol. 2014 Sep;143:61-71.

154 Cvejic J, Bursac M, Atanackovic M. Phytoestrogens: "Estrogene-Like" Phytochemicals. Studies in Natural Products Chemsitry. Elsevier B.V.; 2012. pp. 1-35.

155 Persichini T, Maio N, di Patti MC, Rizzo G, Colasanti M, Musci G. Genistein up-regulates the iron efflux system in glial cells. Neurosci Lett. 2010 Feb;470(2):145-9.

156 Ma WW, Hou CC, Zhou X, Yu HL, Xi YD, Ding J, et al. Genistein alleviates the mitochondria-targeted DNA damage induced by $\beta$-amyloid peptides 25-35 in C6 glioma cells. Neurochem Res. 2013 Jul;38(7):1315-23.

157 Lu H, Shi JX, Zhang DM, Wang HD, Hang $\mathrm{CH}$, Chen HL, et al. Inhibition of hemolysate-induced iNOS and COX-2 expression by genistein through suppression of NFsmall ka, CyrillicB activation in primary astrocytes. J Neurol Sci. 2009 Mar;278(1-2): 91-5.
158 Valles SL, Dolz-Gaiton P, Gambini J, Borras C, Lloret A, Pallardo FV, et al. Estradiol or genistein prevent Alzheimer's disease-associated inflammation correlating with an increase PPAR gamma expression in cultured astrocytes. Brain Res. 2010 Feb;1312:13844.

159 Soltani Z, Khaksari M, Jafari E, Iranpour M, Shahrokhi N. Is genistein neuroprotective in traumatic brain injury? Physiol Behav. 2015 Dec;152 Pt A:26-31.

160 Sinha K, Chaudhary G, Gupta YK. Protective effect of resveratrol against oxidative stress in middle cerebral artery occlusion model of stroke in rats. Life Sci. 2002 Jun; 71(6):655-65.

161 Morissette M, Al Sweidi S, Callier S, Di Paolo T. Estrogen and SERM neuroprotection in animal models of Parkinson's disease. Mol Cell Endocrinol. 2008 Aug;290(1-2):60-9.

162 Pinkerton JV, Thomas S. Use of SERMs for treatment in postmenopausal women. J Steroid Biochem Mol Biol. 2014 Jul;142:14254

163 Mirkin S, Pickar JH. Selective estrogen receptor modulators (SERMs): a review of clinical data. Maturitas. 2015 Jan;80(1):527.

164 Arevalo MA, Diz-Chaves Y, Santos-Galindo M, Bellini MJ, Garcia-Segura LM. Selective oestrogen receptor modulators decrease the inflammatory response of glial cells. J Neuroendocrinol. 2012 Jan;24(1):183-90.

165 Bourque M, Dluzen DE, Di Paolo T. Signaling pathways mediating the neuroprotective effects of sex steroids and SERMs in Parkinson's disease. Front Neuroendocrinol. 2012 Apr;33(2):169-78.

166 Goldstein JS, Sites CK. Selective modulation of sex steroids. Ageing Res Rev. 2002 Feb; $1(1): 17-28$.

167 Kloosterboer HJ. Tibolone: a steroid with a tissue-specific mode of action. J Steroid Biochem Mol Biol. 2001 Jan-Mar;76(1-5):2318.

168 Verheul HA, Kloosterboer HJ. Metabolism of exogenous sex steroids and effect on brain functions with a focus on tibolone. J Steroid Biochem Mol Biol. 2006 Dec;102(1-5):195204.

169 Crespo-Castrillo A, Yanguas-Casás N, Arevalo MA, Azcoitia I, Barreto GE, Garcia-Segura LM. The Synthetic Steroid Tibolone Decreases Reactive Gliosis and Neuronal Death in the Cerebral Cortex of Female Mice After a Stab Wound Injury. Mol Neurobiol. 2018 Nov;55(11):8651-67.

170 Franco Rodríguez NE, Dueñas Jiménez JM, De la Torre Valdovinos B, López Ruiz JR, Hernández Hernández L, Dueñas Jiménez SH. Tamoxifen favoured the rat sensorial cortex regeneration after a penetrating brain injury. Brain Res Bull. 2013 Sep;98:64-75. 
171 López Rodríguez AB, Mateos Vicente B, Romero-Zerbo SY, Rodriguez-Rodriguez N, Bellini MJ, Rodriguez de Fonseca F, et al. Estradiol decreases cortical reactive astrogliosis after brain injury by a mechanism involving cannabinoid receptors. Cereb Cortex. 2011 Sep;21(9):2046-55.

172 Rzemieniec J, Litwa E, Wnuk A, Lason W, Gołas A, Krzeptowski W, et al. Neuroprotective action of raloxifene against hypoxia-induced damage in mouse hippocampal cells depends on ERa but not ER $\beta$ or GPR30 signalling. J Steroid Biochem Mol Biol. 2015 Feb;146:26-37.

173 Rzemieniec J, et al. Neuroprotective action of raloxifene against hypoxia-induced damage in mouse hippocampal cells depends on ER $\alpha$ but not ER $\beta$ or GPR30 signalling. J Steroid Biochem Mol Biol. 2014;146:26-37.

174 Tsai YT, Wang CC, Leung PO, Lin KC, Chio $\mathrm{CC}, \mathrm{Hu} \mathrm{CY}$, et al. Extracellular signal-regulated kinase $1 / 2$ is involved in a tamoxifen neuroprotective effect in a lateral fluid percussion injury rat model. J Surg Res. 2014 Jun;189(1):106-16.

175 Zhou W, Koldzic-Zivanovic N, Clarke CH, de Beun R, Wassermann K, Bury PS, et al. Selective estrogen receptor modulator effects in the rat brain. Neuroendocrinology. 2002 Jan;75(1):24-33.

176 Dehghan F, Khaksari M, Abbasloo E, Shahrokhi N. The Effects of Estrogen Receptors' Antagonist on Brain Edema, Intracranial Pressure and Neurological Outcomes after Traumatic Brain Injury in Rat. Iran Biomed J. 2015;19(3):165-71.

177 Littleton-Kearney MT, Ostrowski NL, Cox DA, Rossberg MI, Hurn PD. Selective estrogen receptor modulators: tissue actions and potential for CNS protection. CNS Drug Rev. 2002;8(3):309-30.

178 Sönmez U, Sönmez A, Erbil G, Tekmen I, Baykara B. Neuroprotective effects of resveratrol against traumatic brain injury in immature rats. Neurosci Lett. 2007 Jun;420(2): 133-7.

179 Wang YP, Lin HP, Chen HM, Kuo YS, Lang MJ, Sun A. Hemoglobin, iron, and vitamin B12 deficiencies and high blood homocysteine levels in patients with anti-thyroid autoantibodies. J Formos Med Assoc. 2014 Mar; 113(3):155-60.

180 Zhou XM, Zhou ML, Zhang XS, Zhuang Z, Li T, Shi JX, et al. Resveratrol prevents neuronal apoptosis in an early brain injury model. J Surg Res. 2014 Jun;189(1):159-65.

181 Pawlak J, Karolczak M, Krust A, Chambon $\mathrm{P}$, Beyer C. Estrogen receptor- $\alpha$ is associated with the plasma membrane of astrocytes and coupled to the MAP/Src-kinase pathway. Glia. 2005 May;50(3):270-5.

182 Zhang L, Li B, Zhao W, Chang YH, Ma W, Dragan M, et al. Sex-related differences in MAPKs activation in rat astrocytes: effects of estrogen on cell death. Brain Res Mol Brain Res. 2002 Jun;103(1-2):1-11.
183 Buchanan CD, Mahesh VB, Brann DW. Estrogen-astrocyte-luteinizing hormone-releasing hormone signaling: a role for transforming growth factor-beta(1). Biol Reprod. 2000 Jun;62(6):1710-21.

184 Hösli E, Rühl W, Hösli L. Histochemical and electrophysiological evidence for estrogen receptors on cultured astrocytes: colocalization with cholinergic receptors. Int J Dev Neurosci. 2000 Feb;18(1):101-11.

185 Lee D, Smallbone K, Dunn WB, Murabito E, Winder CL, Kell DB, et al. Improving metabolic flux predictions using absolute gene expression data. BMC Syst Biol. 2012 Jun; 6(1):73-73.

186 Marino M, Galluzzo P, Ascenzi P. Estrogen signaling multiple pathways to impact gene transcription. Curr Genomics. 2006;7(8): 497-508.

187 Paterni I, Granchi C, Katzenellenbogen JA, Minutolo F. Estrogen receptors alpha (ER $\alpha)$ and beta (ER $\beta$ ): subtype-selective ligands and clinical potential. Steroids. $2014 \mathrm{Nov}$;90: 13-29.

188 Santagati S, Melcangi RC, Celotti F, Martini L, Maggi A. Estrogen receptor is expressed in different types of glial cells in culture. J Neurochem. 1994 Dec;63(6):2058-64.

189 Arimoto JM, Wong A, Rozovsky I, Lin SW, Morgan TE, Finch CE. Age increase of estrogen receptor- $\alpha(E R \alpha)$ in cortical astrocytes impairs neurotrophic support in male and female rats. Endocrinology. 2013 Jun;154(6): 2101-13.

190 Azcoitia I, Sierra A, Garcia-Segura LM. Localization of estrogen receptor beta-immunoreactivity in astrocytes of the adult rat brain. Glia. 1999 May;26(3):260-7.

191 Langub MC Jr, Watson RE Jr. Estrogen receptor-immunoreactive glia, endothelia, and ependyma in guinea pig preoptic area and median eminence: electron microscopy. Endocrinology. 1992 Jan;130(1):364-72.

192 Donahue JE, Stopa EG, Chorsky RL, King JC, Schipper HM, Tobet SA, et al. Cells containing immunoreactive estrogen receptoralpha in the human basal forebrain. Brain Res. 2000 Feb;856(1-2):142-51.

193 Jakab RL, Wong JK, Belcher SM. Estrogen receptor beta immunoreactivity in differentiating cells of the developing rat cerebellum. J Comp Neurol. 2001 Feb;430(3):396-409.

194 Milner TA, McEwen BS, Hayashi S, Li CJ, Reagan LP, Alves SE. Ultrastructural evidence that hippocampal alpha estrogen receptors are located at extranuclear sites. J Comp Neurol. 2001 Jan;429(3):355-71.

195 Savaskan E, Olivieri G, Meier F, Ravid R, Müller-Spahn F. Hippocampal estrogen $\beta$-receptor immunoreactivity is increased in Alzheimer's disease. Brain Res. 2001 Jul; 908(2):113-9.
196 Karki P, Smith K, Johnson J Jr, Lee E. Astrocyte-derived growth factors and estrogen neuroprotection: role of transforming growth factor- $\alpha$ in estrogen-induced upregulation of glutamate transporters in astrocytes. Mol Cell Endocrinol. 2014 May; 389(1-2):58-64.

197 Karki P, Webb A, Zerguine A, Choi J, Son DS, Lee E. Mechanism of raloxifene-induced upregulation of glutamate transporters in rat primary astrocytes. Glia. 2014 Aug;62(8): 1270-83.

198 Spence RD, Wisdom AJ, Cao Y, Hill HM, Mongerson CR, Stapornkul B, et al. Estrogen mediates neuroprotection and anti-inflammatory effects during EAE through ERa signaling on astrocytes but not through ER $\beta$ signaling on astrocytes or neurons. J Neurosci. 2013 Jun;33(26):10924-33.

199 Garcia-Estrada J, Del Rio JA, Luquin S, Soriano E, Garcia-Segura LM. Gonadal hormones down-regulate reactive gliosis and astrocyte proliferation after a penetrating brain injury. Brain Res. 1993 Nov;628(1-2): 271-8.

200 García-Estrada J, Luquín S, Fernández AM, Garcia-Segura LM. Dehydroepiandrosterone, pregnenolone and sex steroids down-regulate reactive astroglia in the male rat brain after a penetrating brain injury. Int J Dev Neurosci. 1999 Apr;17(2):145-51.

201 Bagheri M, Roghani M, Joghataei MT, Mohseni S. Genistein inhibits aggregation of exogenous amyloid-beta ${ }_{1-40}$ and alleviates astrogliosis in the hippocampus of rats. Brain Res. 2012 Jan;1429:145-54.

202 Colón JM, González PA, Cajigas Á, Maldonado WI, Torrado AI, Santiago JM, et al. Continuous tamoxifen delivery improves locomotor recovery $6 \mathrm{~h}$ after spinal cord injury by neuronal and glial mechanisms in male rats. Exp Neurol. 2018 Jan;299 Pt A:109-21.

203 Danbolt NC. Glutamate uptake. Prog Neurobiol. 2001 Sep;65(1):1-105.

204 Yuzefovych LV, Musiyenko SI, Wilson GL, Rachek LI. Mitochondrial DNA damage and dysfunction, and oxidative stress are associated with endoplasmic reticulum stress, protein degradation and apoptosis in high fat diet-induced insulin resistance mice. PLoS One. 2013;8(1):e54059.

205 Azcoitia I, Sierra A, Garcia-Segura LM. Estradiol prevents kainic acid-induced neuronal loss in the rat dentate gyrus. Neuroreport. 1998 Sep;9(13):3075-9.

206 Azcoitia I, Sierra A, Garcia-Segura LM. Neuroprotective effects of estradiol in the adult rat hippocampus: interaction with insulinlike growth factor-I signalling. J Neurosci Res. 1999 Dec;58(6):815-22.

207 Azcoitia I, Fernandez-Galaz C, Sierra A, Garcia-Segura LM. Gonadal hormones affect neuronal vulnerability to excitotoxininduced degeneration. J Neurocytol. 1999 Sep;28(9):699-710. 
208 Picazo O, Azcoitia I, Garcia-Segura LM. Neuroprotective and neurotoxic effects of estrogens. Brain Res. 2003 Nov;990(1-2):207.

209 Picazo O, Becerril-Montes A, HuidobroPerez D, Garcia-Segura LM. Neuroprotective actions of the synthetic estrogen 17alpha-ethynylestradiol in the hippocampus. Cell Mol Neurobiol. 2010 Jul;30(5):675-82.

210 Shy H, Malaiyandi L, Timiras PS. Protective action of 17beta-estradiol and tamoxifen on glutamate toxicity in glial cells. Int $\mathrm{J}$ Dev Neurosci. 2000 Apr-Jun;18(2-3):289-97.

211 dos Santos AQ, Nardin P, Funchal C, de Almeida LM, Jacques-Silva MC, Wofchuk ST, et al. Resveratrol increases glutamate uptake and glutamine synthetase activity in C6 glioma cells. Arch Biochem Biophys. 2006 Sep; 453(2):161-7.

212 de Almeida LM, Piñeiro CC, Leite MC, Brolese G, Tramontina F, Feoli AM, et al. Resveratrol increases glutamate uptake, glutathione content, and S100B secretion in cortical astrocyte cultures. Cell Mol Neurobiol. 2007 Aug;27(5):661-8.

213 Moreira PI, Custódio JB, Oliveira CR, Santos MS. Hydroxytamoxifen protects against oxidative stress in brain mitochondria. Biochem Pharmacol. 2004 Jul;68(1):195-204.

214 Moreira PI, Custódio JB, Oliveira CR, Santos MS. Brain mitochondrial injury induced by oxidative stress-related events is prevented by tamoxifen. Neuropharmacology. 2005 Mar;48(3):435-47.

215 Thiede A, Gellerich FN, Schönfeld P, Siemen D. Complex effects of $17 \beta$-estradiol on mitochondrial function. Biochim Biophys Acta. 2012 Oct; 1817(10):1747-53.

216 Guo J, Duckles SP, Weiss JH, Li X, Krause DN. 17 $\beta$-Estradiol prevents cell death and mitochondrial dysfunction by an estrogen receptor-dependent mechanism in astrocytes after oxygen-glucose deprivation/reperfusion. Free Radic Biol Med. 2012 Jun; 52(11-12):2151-60.

217 Ates O, Cayli S, Altinoz E, Gurses I, Yucel N, Sener M, et al. Neuroprotection by resveratrol against traumatic brain injury in rats. Mol Cell Biochem. 2007 Jan;294(1-2):13744.

218 Klinge CM. Estrogens regulate life and death in mitochondria. J Bioenerg Biomembr. 2017 Aug;49(4):307-24.

219 Simpkins JW, Yang SH, Sarkar SN, Pearce V. Estrogen actions on mitochondria-physiological and pathological implications. Mol Cell Endocrinol. 2008 Aug;290(1-2):51-9.

220 Simpkins JW, Dykens JA. Mitochondrial mechanisms of estrogen neuroprotection. Brain Res Brain Res Rev. 2008 Mar;57(2): 421-30.

221 Kubik LL, Philbert MA. The role of astrocyte mitochondria in differential regional susceptibility to environmental neurotoxicants: tools for understanding neurodegeneration. Toxicol Sci. 2015 Mar;144(1):7-16.
222 Moreira PI, Custódio JB, Nunes E, Oliveira PJ, Moreno A, Seiça R, et al. Mitochondria from distinct tissues are differently affected by $17 \beta$-estradiol and tamoxifen. J Steroid Biochem Mol Biol. 2011 Jan;123(1-2):8-16.

223 Yang SH, Liu R, Perez EJ, Wen Y, Stevens SM Jr, Valencia T, et al. Mitochondrial localization of estrogen receptor beta. Proc Natl Acad Sci USA. 2004 Mar;101(12):4130-5.

224 Aoki E, Yano R, Yokoyama H, Kato H, Araki T. Role of nuclear transcription factor kappa B (NF-kappaB) for MPTP (1-methyl4-phenyl-1,2,3,6-tetrahyropyridine)-induced apoptosis in nigral neurons of mice. Exp Mol Pathol. 2009 Feb;86(1):57-64.

225 Cerciat M, Unkila M, Garcia-Segura LM, Arevalo MA. Selective estrogen receptor modulators decrease the production of interleukin- 6 and interferon- $\gamma$-inducible protein-10 by astrocytes exposed to inflammatory challenge in vitro. Glia. $2010 \mathrm{Jan} ; 58(1)$ : 93-102.

226 Khaksari M, Soltani Z, Shahrokhi N, Moshtaghi G, Asadikaram G. The role of estrogen and progesterone, administered alone and in combination, in modulating cytokine concentration following traumatic brain injury. Can J Physiol Pharmacol. 2011 Jan;89(1):31-40.

227 Liu MH, Lin YS, Sheu SY, Sun JS. Anti-inflammatory effects of daidzein on primary astroglial cell culture. Nutr Neurosci. 2009 Jun;12(3):123-34.

228 Sarkaki AR, Khaksari Haddad M, Soltani Z, Shahrokhi N, Mahmoodi M. Time- and dose-dependent neuroprotective effects of sex steroid hormones on inflammatory cytokines after a traumatic brain injury. J Neurotrauma. 2013 Jan;30(1):47-54.

229 Zonta M, Angulo MC, Gobbo S, Rosengarten B, Hossmann KA, Pozzan T, et al. Neuron-to-astrocyte signaling is central to the dynamic control of brain microcirculation. Nat Neurosci. 2003 Jan;6(1):43-50.

230 Levi G, Wilkin GP, Ciotti MT, Johnstone S. Enrichment of differentiated, stellate astrocytes in cerebellar interneuron cultures as studied by GFAP immunofluorescence and autoradiographic uptake patterns with $[3 \mathrm{H}]$ $\mathrm{D}$-aspartate and [3H]GABA. Brain Res. 1983 Nov;312(2):227-41.

231 Newman DJ, Cragg GM. Natural products as sources of new drugs over the last 25 years. J Nat Prod. 2007 Mar;70(3):461-77.

232 Aschner M. Neuron-astrocyte interactions: implications for cellular energetics and antioxidant levels. Neurotoxicology. 2000 Dec; 21(6):1101-7.

233 Nedergaard M, Ransom B, Goldman SA. New roles for astrocytes: redefining the functional architecture of the brain. Trends Neurosci. 2003 Oct;26(10):523-30.

234 Myer DJ, Gurkoff GG, Lee SM, Hovda DA, Sofroniew MV. Essential protective roles of reactive astrocytes in traumatic brain injury. Brain. 2006 Oct;129(Pt 10):2761-72.
235 Gee JR, Keller JN. Astrocytes: regulation of brain homeostasis via apolipoprotein $\mathrm{E}$. Int J Biochem Cell Biol. 2005 Jun;37(6):114550.

236 Di Giorgio FP, Carrasco MA, Siao MC, Maniatis T, Eggan K. Non-cell autonomous effect of glia on motor neurons in an embryonic stem cell-based ALS model. Nat Neurosci. 2007 May; 10(5):608-14.

237 John GR, Lee SC, Brosnan CF. Cytokines: powerful regulators of glial cell activation. Neuroscientist. 2003 Feb;9(1):10-22.

238 Smith GM, Strunz C. Growth factor and cytokine regulation of chondroitin sulfate proteoglycans by astrocytes. Glia. 2005 Nov; 52(3):209-18.

239 Streit WJ, Hurley SD, McGraw TS, SempleRowland SL. Comparative evaluation of cytokine profiles and reactive gliosis supports a critical role for interleukin-6 in neuronglia signaling during regeneration. J Neurosci Res. 2000 Jul;61(1):10-20.

240 Farina C, Aloisi F, Meinl E. Astrocytes are active players in cerebral innate immunity. Trends Immunol. 2007 Mar;28(3):138-45.

241 Hamby ME, Coppola G, Ao Y, Geschwind DH, Khakh BS, Sofroniew MV. Inflammatory mediators alter the astrocyte transcriptome and calcium signaling elicited by multiple G-protein-coupled receptors. J Neurosci. 2012 Oct;32(42):14489-510.

242 Bekar LK, He W, Nedergaard M. Locus coeruleus alpha-adrenergic-mediated activation of cortical astrocytes in vivo. Cereb Cortex. 2008 Dec;18(12):2789-95.

243 Braissant O, McLin VA, Cudalbu C. Ammonia toxicity to the brain. J Inherit Metab Dis. 2013 Jul;36(4):595-612.

244 Chandra K, et al. Protection against FCA induced oxidative stress induced DNA damage as a model of arthritis and In vitro anti-arthritic potential of Costus speciosus Rhizome extract. Int J Pharmacognosy Phytochem Res. 2015;7(2):383-9.

245 Lee HJ, Suk JE, Patrick C, Bae EJ, Cho JH, Rho S, et al. Direct transfer of $\alpha$-synuclein from neuron to astroglia causes inflammatory responses in synucleinopathies. J Biol Chem. 2010 Mar;285(12):9262-72.

246 Simpson JE, Ince PG, Lace G, Forster G, Shaw PJ, Matthews F, et al.; MRC Cognitive Function and Ageing Neuropathology Study Group. Astrocyte phenotype in relation to Alzheimer-type pathology in the ageing brain. Neurobiol Aging. 2010 Apr;31(4): 578-90.

247 Kang W, Hébert JM. Signaling pathways in reactive astrocytes, a genetic perspective. Mol Neurobiol. 2011 Jun;43(3):147-54.

248 Chen Y, Miles DK, Hoang T, Shi J, Hurlock E, Kernie SG, et al. The basic helix-loop-helix transcription factor olig2 is critical for reactive astrocyte proliferation after cortical injury. J Neurosci. 2008 Oct;28(43):109839. 
249 Beck H, Semisch M, Culmsee C, Plesnila N, Hatzopoulos AK. Egr-1 regulates expression of the glial scar component phosphacan in astrocytes after experimental stroke. Am J Pathol. 2008 Jul;173(1):77-92.

250 Bundesen LQ, Scheel TA, Bregman BS, Kromer LF. Ephrin-B2 and EphB2 regulation of astrocyte-meningeal fibroblast interactions in response to spinal cord lesions in adult rats. J Neurosci. 2003 Aug;23(21): 7789-800.

251 Brambilla R, Hurtado A, Persaud T, Esham $\mathrm{K}$, Pearse DD, Oudega M, et al. Transgenic inhibition of astroglial NF- $\kappa$ B leads to increased axonal sparing and sprouting following spinal cord injury. J Neurochem. 2009 Jul;110(2):765-78.

252 Panenka W, Jijon H, Herx LM, Armstrong JN, Feighan D, Wei T, et al. P2X7-like receptor activation in astrocytes increases chemokine monocyte chemoattractant protein-1 expression via mitogen-activated protein $\mathrm{ki}$ nase. J Neurosci. 2001 Sep;21(18):7135-42.

253 Qin H, Niyongere SA, Lee SJ, Baker BJ, Benveniste EN. Expression and functional significance of SOCS-1 and SOCS- 3 in astrocytes. J Immunol. 2008 Sep;181(5):3167-76.

254 Shih AY, Johnson DA, Wong G, Kraft AD, Jiang L, Erb H, et al. Coordinate regulation of glutathione biosynthesis and release by Nrf2-expressing glia potently protects neurons from oxidative stress. J Neurosci. 2003 Apr;23(8):3394-406.

255 Vargas MR, Johnson DA, Sirkis DW, Messing A, Johnson JA. Nrf2 activation in astrocytes protects against neurodegeneration in mouse models of familial amyotrophic lateral sclerosis. J Neurosci. 2008 Dec;28(50): 13574-81.

256 Hamby ME, Hewett JA, Hewett SJ. TGF-betal potentiates astrocytic nitric oxide production by expanding the population of astrocytes that express NOS-2. Glia. 2006 Nov; 54(6):566-77.
257 Figiel M, Maucher T, Rozyczka J, Bayatti N, Engele J. Regulation of glial glutamate transporter expression by growth factors. Exp Neurol. 2003 Sep;183(1):124-35.

258 Li LB, Toan SV, Zelenaia O, Watson DJ, Wolfe JH, Rothstein JD, et al. Regulation of astrocytic glutamate transporter expression by Akt: evidence for a selective transcriptional effect on the GLT-1/EAAT2 subtype. J Neurochem. 2006 May;97(3):759-71.

259 Khaksari M, Hajializadeh Z, Shahrokhi N, Esmaeili-Mahani S. Changes in the gene expression of estrogen receptors involved in the protective effect of estrogen in rat's trumatic brain injury. Brain Res. 2015 Aug; 1618:1-8.

260 Day NL, Floyd CL, D’Alessandro TL, Hubbard WJ, Chaudry IH. 17 $\beta$-estradiol confers protection after traumatic brain injury in the rat and involves activation of $G$ protein-coupled estrogen receptor 1. J Neurotrauma. 2013 Sep;30(17):1531-41.

261 Zhang YQ, Shi J, Rajakumar G, Day AL, Simpkins JW. Effects of gender and estradiol treatment on focal brain ischemia. Brain Res. 1998 Feb;784(1-2):321-4.

262 Espinosa-Raya J, Neri-Gómez T, OrozcoSuárez S, Campos MG, Guerra-Araiza C. Chronic administration of tibolone modulates anxiety-like behavior and enhances cognitive performance in ovariectomized rats. Horm Behav. 2012 Jan;61(1):76-83.

263 Farfán-García ED, Castillo-Hernández MC, Pinto-Almazán R, Rivas-Arancibia S, Gallardo JM, Guerra-Araiza C. Tibolone prevents oxidation and ameliorates cholinergic deficit induced by ozone exposure in the male rat hippocampus. Neurochem Res. 2014 Sep;39(9):1776-86.

264 Pinto-Almazán R, Rivas-Arancibia S, Farfán-García ED, Rodríguez-Martínez E, Guerra-Araiza C. Neuroprotective effects of tibolone against oxidative stress induced by ozone exposure. Rev Neurol. 2014 May; 58(10):441-8.

265 Fluck E, File SE, Rymer J. Cognitive effects of 10 years of hormone-replacement therapy with tibolone. J Clin Psychopharmacol. 2002 Feb;22(1):62-7.
266 Sato K, Saito Y, Oka J, Ohwada T, Nakazawa K. Effects of tamoxifen on L-glutamate transporters of astrocytes. J Pharmacol Sci. 2008 Jun;107(2):226-30.

267 Karki P, Webb A, Smith K, Lee K, Son DS, Aschner M, et al. cAMP response elementbinding protein (CREB) and nuclear factor $\kappa \mathrm{B}$ mediate the tamoxifen-induced up-regulation of glutamate transporter 1 (GLT-1) in rat astrocytes. J Biol Chem. 2013 Oct; 288(40):28975-86.

268 Hung KL, Wang CC, Wang SJ. Cellular mechanisms of acute decrease of glutamate release induced by raloxifene in rat cerebral cortex. Neuropharmacology. 2011 Jul-Aug; 61(1-2):293-304

269 Ismailoğlu Ö, Oral B, Sütcü R, Kara Y, Tomruk O, Demir N. Neuroprotective effects of raloxifene on experimental spinal cord injury in rats. Am J Med Sci. 2013 Jan;345(1) $39-44$.

270 Mosquera L, Colón JM, Santiago JM, Torrado AI, Meléndez $M$, Segarra $A C$, et al. Tamoxifen and estradiol improved locomotor function and increased spared tissue in rats after spinal cord injury: their antioxidant effect and role of estrogen receptor alpha. Brain Res. 2014 May;1561:11-22.

271 Tian DS, Liu JL, Xie MJ, Zhan Y, Qu WS, Yu $\mathrm{ZY}$, et al. Tamoxifen attenuates inflammatory-mediated damage and improves functional outcome after spinal cord injury in rats. J Neurochem. 2009 Jun;109(6):165867.

272 Shi R, Wang S, Qi X, Chen S, Chen P, Zhang Q. Lose dose genistein inhibits glucocorticoid receptor and ischemic brain injury in female rats. Neurochem Int. 2014 Jan;65(1): $14-22$.

273 Liu R, Zhong X, Zeng J, Huang Z, Li X, Xiao $\mathrm{H}$, et al. $3^{\prime}$-Daidzein sulfonate sodium inhibits neuronal apoptosis induced by cerebral ischemia-reperfusion. Int J Mol Med. 2017 Apr;39(4):1021-8. 